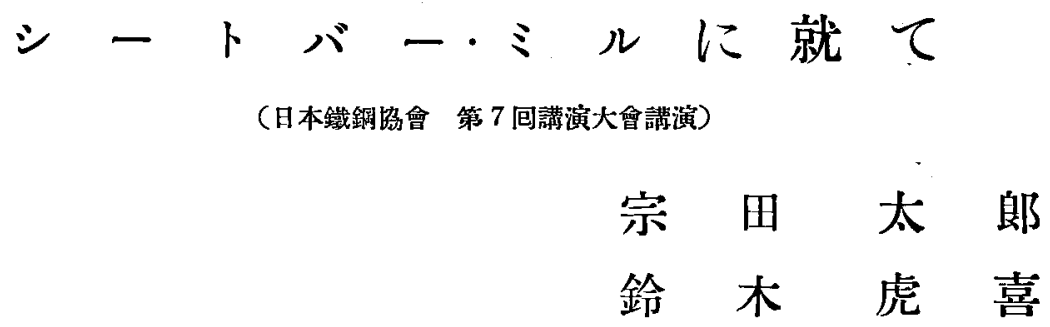

ON THE OPERATION OF THE SHEET BAR MILL

by T. Soda and T. Suzuki.

SINOPSIS. The Sheet Bar Mill, designed and manufactured by the Krupp Grüson Works in Germany, was installed in The Plate and Sheet Rolling Mills on June 1929 to furnish 200,000 tons of sheet bar yearly for black sheet mills in the same compound.

At the beginning of operation, we had a little difficulty to attain predetermined productions, but by co-operation of engineers and working men it soon became evident that the maximum designed capacity could easily be surpassed when needed. The results are described elsewhere in this paper.

The present paper describes the general arrangement of furnaces and mills, results of rolling operation and also research works which have been performed during routine works, and is arranged as follows:-

I. Introduction

II. General arrangements

III. Reheating furnaces-

1. Construction together with special features and endurance tests

2. Working methods and temperature distributions in the furnaces

3. Gas and Air consumption, theoretical and practical

4. Pyrometric efficiency

5. Heat balancé

IV. Rolling mills proper- .

1. Mills and accessories

3. Methods of rolling-

(1) Classification of sheet bars to be rolled

(2) Rolls.

(3) Rolling operation

(4) Adjustment of drafts which are to be distribuled on four stands of the continuous finishing mill

3. Results of operation

4. Electric power saving by an improved lubrication

5. Experiments on the power consumption which is required for rolling an ingot into sheet bars of specifed dimensions

I. 緒 言

此のシートバー・ミルは當川崎造船所製鍍工場

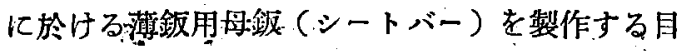

的の隲設立せられたるものにして：昭和 4 年 6

月の創策にかなる。而して加熱嘘は獨逸 Ruppm- ann 會靕の設計になり、歷㢟機及び其他の附屬機 械設倩は同上 Krupp Grüson 工場の設計製作に なり、原釦機は同上 Siemens Schuckert 工場の製 作になるものなり。此の立場は年額 200,000 㫛の シートバーを製作する能力を准し、且つ尚质相當 
の餘裕を有す。

次に此の工場の加趡爐と壓延機との各々に就き

調查研究せる結果を述ぶ。

\section{II. エ場設備の概要}

第1 圖化之走京。

1. 銅塊裴入装置 (Blocksto:svorrichtung)

2. 加 熱 嘘 (Wärmofen) $\neq$.

3. 銅塊搬出裝置 ( Blocktransportvörrichtung)

4. ローラーテーブル (Rollgang)

5. 銅塊方向棘換㱔置 (Blo. kdrehvorrichtung)

6. チルチングテープル (Wipptisch)

第!圆平銅工場全蹬配置圖

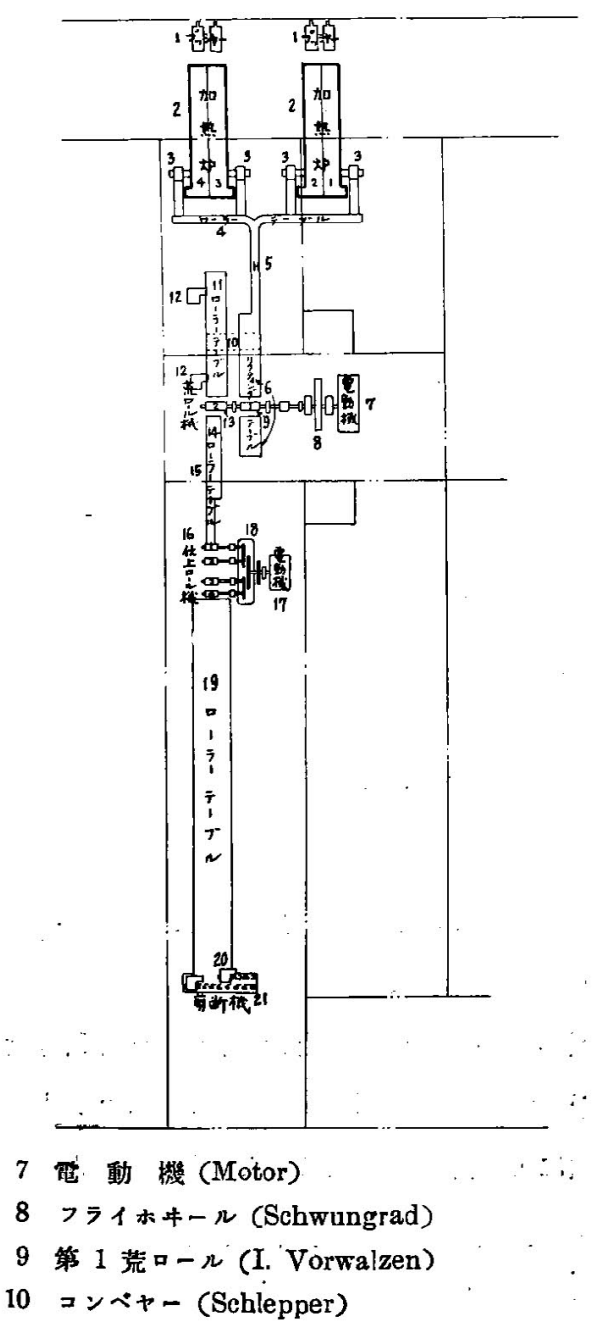

11. ローシーテーブル (Rollgang)

12. 前 斷 機 (Schere)

13. 第 2 茫口ール (II. Vorwalzen)

14. チルチングテーブル (Wipptiseh)

15. ローラーテーブル (Rollgang)

16. 速䇱ロール (Kontin Walzen)

17. 勧预 譏 (Motor)

18. ギャリング (Vorgelege)

19. クーリングテーブル(Warmbett)

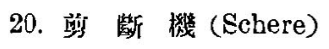

21. 搬出装置 (Transportvorrichtung)

\section{III. 加熱爐に就て}

1. 爐の槛造及ざ其の特徽と耐久性

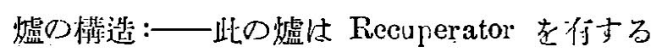

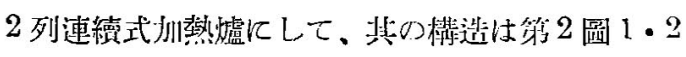
に示す如きものなり。

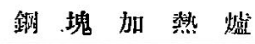

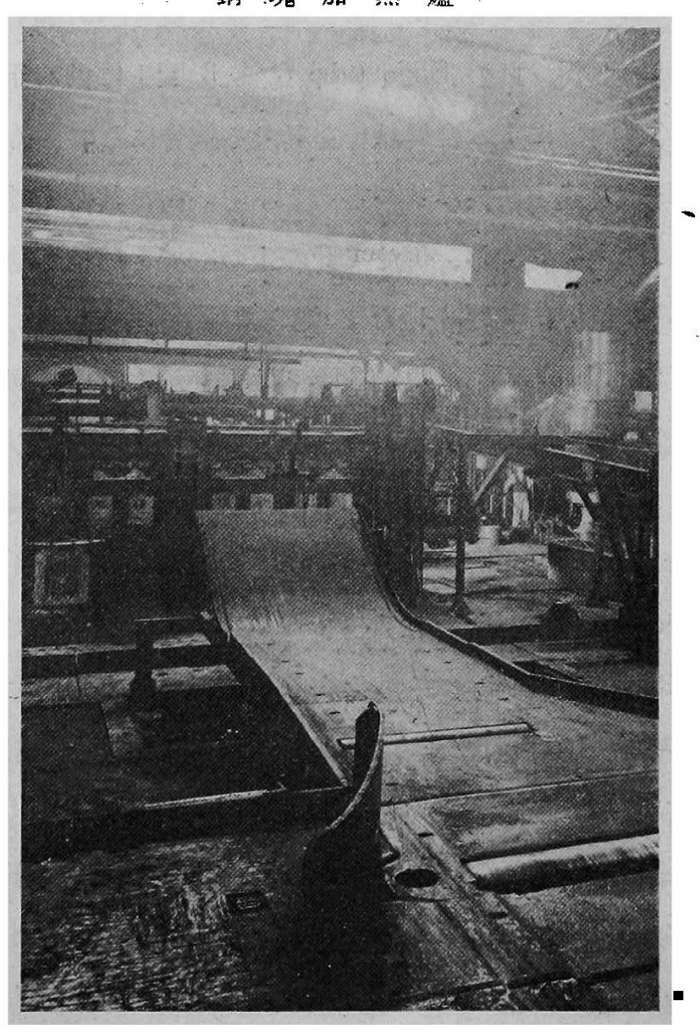

爐の大さは長さ $18,80 \%) m$ 、幅 $2,660 \mathrm{~mm}$ 、地上， 


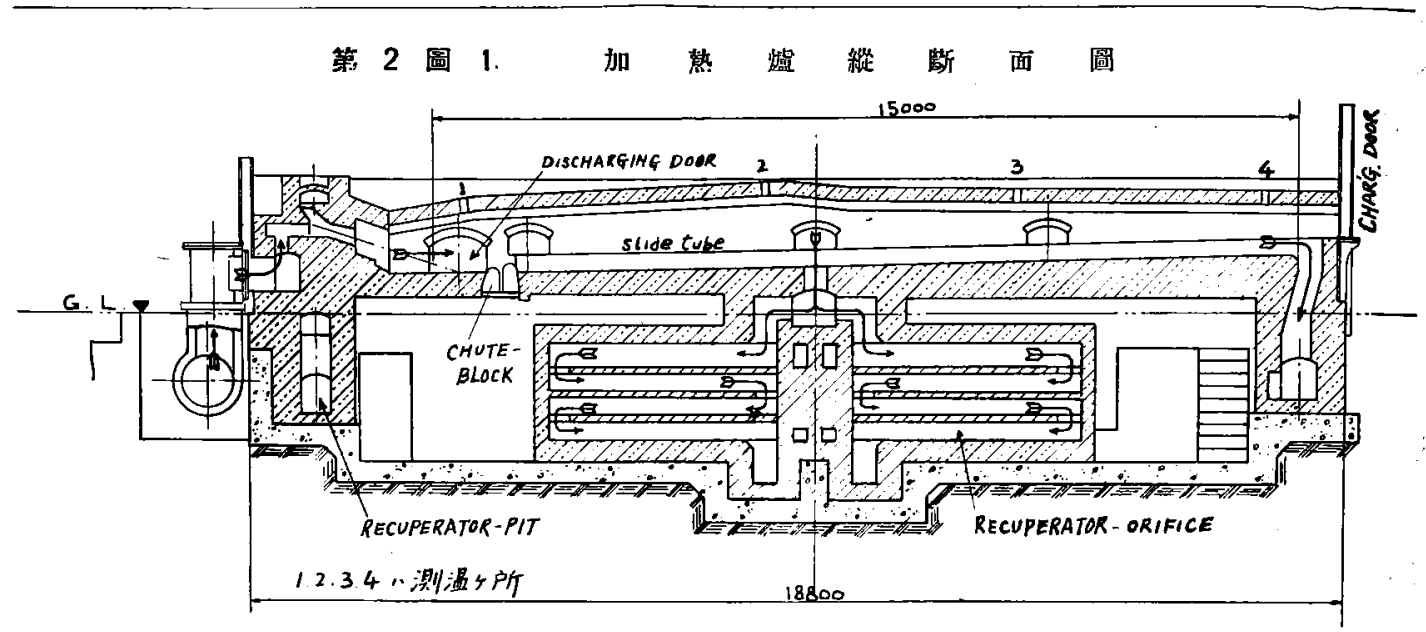

高さ $2,200 \mathrm{~mm}$ にして、爐床上に長さ $14,550 \mathrm{~mm}$ の 2 本の Slide tube (Gleitrohr) あり。鋼塊(大 口 $340 \mathrm{~mm}$ 角. 小口 $300 \mathrm{~mm}$ 角。長さ約 1,400 $m m$ 、重量 93 ) 乃至 $1,000 \mathrm{~kg}$ ) は此の上に連緢的 に裝入さる」ものにして、爐 1 基に就き 42 個を 收管し得、此の Slide tube は第 3 圆上に見る如 く、內部に 1 本の畏鍮管を具たる鋼管にして、冷 却水を通和。矢は其の方向を示す。少海其の先端 には之を支持し、件せて此の上の鋼塊を前爐床適 當の位置に轉倒せしむる働をなす Chute block （Sturzbock）あり。第3圖下は之を示す。之没同 楊內部江冷却水を通和。

互斯は吹出口上り矢の方向に來り。空氣は相隣 れる嘘の中間壁より誘導され、邆風機を經て Recuperator orifice に入り、此處にて豫熱されて Recuperatorpit に一度集合し、吹出口ょり爐內に 入る。Recuperator は良質のシャモツト煉瓦を朋 ひて極く精磼に組立られたるるのにして、横に 9 段、縱に 4 段の Orifice t有し、廢萧瓦斯と空氣 とは相隣れる Orifice を反對の方向に通過し、此

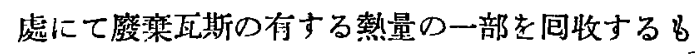
のなり。
第 2 圖 2 .

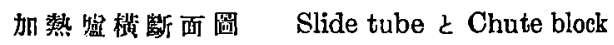
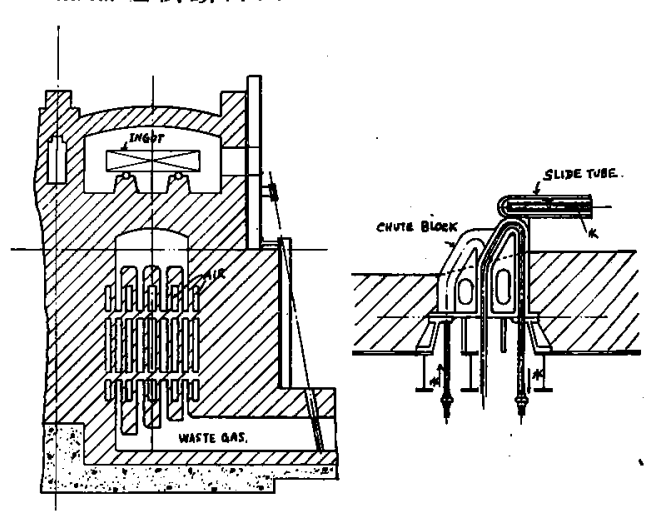

嘘構造上心特徵:——此の爐は前述の如き Recuperator を有し、之によりて空氣を通例 $300^{\circ} \mathrm{C} \sim$ $350=\mathrm{C}$ に䂆熱して朋ひ得るものなり。元隶此の種 の Recuperator 使用上には稙々の困難あるに關世

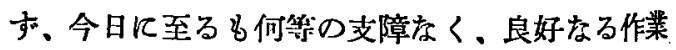
能率を擧げつよある事は、此心爐に於ける第10 特色女なすべく、例人ば今 Recuperator を通過せ し空氣が $300^{\circ} \mathrm{C}$ の熱風となりたりとせば、之れ が含む熱量は Mallard 及び Le, Chatelier 氏1)の 比熱式により計算方れば 193,131 k.cal/hr となる。

1) Richards, Metallurgical Calculations; Part one 


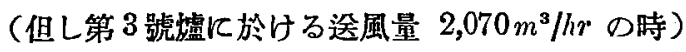
當所使用の援順炭に就ての實测に徒れば。石炭 1 $k g$ の發熱量は 6,870 k.cal なるにより。上記熱量 の石炭當量は

$$
193,131 \div 6,870=28 \mathrm{~kg} . \mathrm{coal} / \mathrm{hr}
$$

なり。他の 3 点共殆んど同樣につを、全體にては $112 \mathrm{~kg} . c o \alpha l / \mathrm{hr}$ となる。

此の嘘に於ける加熱速度は、後部より裝入して 前橫部より抽出する迄約 4 時閒を要するるのにし て、此の間に壓延溫度約 $1,200^{\prime} \mathrm{C}$ 冈外に加熱され 何等の故障なく連䋶的に大量州熱をなすに邀當す るものなり。此種州熱爐に於ては、鋼塊の Slide tube に接触する部分法、冷却水の第几熱を葬は れ片熱となるものなるが、之を甫ふ爲に Chute

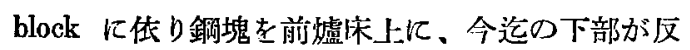
對にト部となる如く轉覆せしめ、そのま〉約 2 分 間あらしめ、上床にて然燒する瓦斯の反射熱によ り熱の不平均を補はしむ。

曥各部の耐久性:一一此の爐に於て最も重要な る部分にして早く損ぜられ易を所は瓦斯吹出口。 前曥床、 Recuperator orifice, Chute block 筹なり 瓦斯吹出口柱嘘內最高溫の所なるを以て損ぜられ 易し。然るに爐內 Flame zone の流れはての傾科 如何により甚だしく影響さる」ものなるが故に、 絕えす之に注意し、少しの崩損にも之れが修理を 行ひつ১あり。前旗床も之れに次ぐ高溫の所にし て、鑛㳯の成生盛んに、且つ鍓塊轉覆の際强を衝 媻を受くる第に損ぜらる」るのなるが、此處には Chrome brick を敷きて之を緩和し、鑛㳯は此處 に於てのみ成生するるのなるを以て此の部分の嘘 床手入にはドロマイト、マグネシャ煉瓦屑、䖝石 等を適當に投入して均し、且つ鋼滓の流れを促し
て之を Slag portより受くるものなり。Recuperator orifice は庭萧瓦斯の通過する最上部が、時 により鑛㳯により埋めらるよ事あり。之れは鑛滵 が Recuperatorの入口上り少量づょ長き時日の間 に浸入するるのなるが故に、かいる時には設けら れてる掃除口を開をて之を除去す。

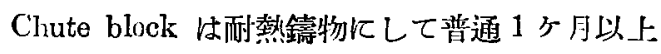
長きは牛ヶ年の使用に耐ゆるものなり。然れども 時には逥を゙不具合のものあり、偨か 1 週間にして 取替えたる例すり。菆近は使用上及ず製作上の研

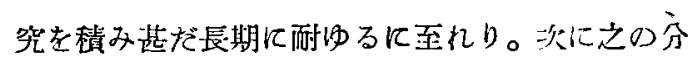
析の一例を示す。

\begin{tabular}{cccccccc}
\multicolumn{10}{c}{ 第 } & \multicolumn{1}{c}{ 表 } \\
$C^{\prime}$ & $A r n$ & $S i$ & $P$ & $S$ & $C_{u}$ & $N_{i}$ & $C_{r}$ \\
0.18 & 0.47 & 0.09 & 0.009 & 0.006 & 0.26 & $2 \cdot 65$ & 0.48
\end{tabular}

次沼和 5 年 4 月 20 日上り同 6 年 6 月 30 日に至る間つClute bock の耐久日數を各嘘に就 て示せば炏の如し。

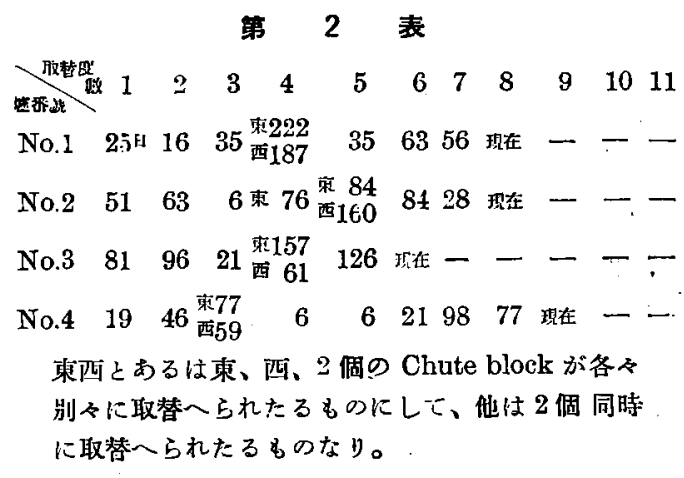

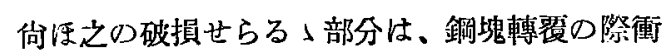
整学受くる上部の一部分のみなるを以て、ての部 分古瓦斯鎔接几依つて修理せば、新品之何等變り なをものとなり、何度も使朋に耐ゆ。

Slide tube は耐樊鋼管にして、創業牛ヶ年後之 が检查を行ひたるに、損耗度は茲か $1.5 \mathrm{~mm}$ 位に 過ぎ。之を $90^{\circ}$ ，趣喠して据付直しをなし、其後 


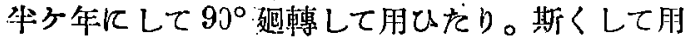
ひらるつ䉆長期の使用に耐ゆ。 Slide tube 分析の 一例を示せば次の如し。

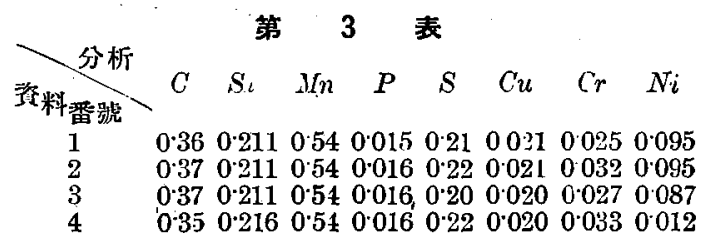

\section{2. 鋼塊加熱作業方法と爐內溫度の分布}

先づ瓦斯と室氣とを適當の割合に揆り、各唣き口 ょb Flame zone の流れ。色. 長さ等を覘き見て 注意し乍ら加熱老行的。爐各部郎ち天井 (第 1 圆 1 の 1,2,3,4 は其の湘定場所を示す)、Recuprator 內部、廢栾瓦斯、熱風、Recuperator 在通過 せる筬葉瓦斯等の溫度は、夫ょの場所に取付けた るPyrometerに上り测定す。瓦斯使用量住 Debro

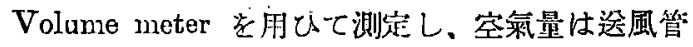
の一部に設計の上取付けたる Stauscheibe の示す

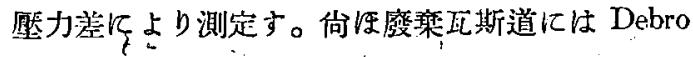
$\mathrm{CO}_{2}$ Recorder 取付け $\mathrm{CO}_{2}$ の量在测定す。以 上の各計器を良く利用して理論と筫際との一致を 目標に作策をなしつょあり。

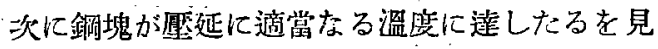

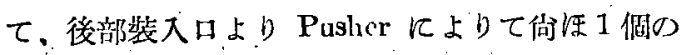
銓塊を押入るれば、最前端の銓塊は Chute block の働により、牛䞤博をなして前䲣床上に落つ。之 約 2 分閏保熱したる後。抽出して是延機に送る 銅塊州蓺の際 Recuperator の溫度考豫め或程度迄 上最せしむる事は重要なる事にして、此の䀀度如 何によりて虚の能率は湛だしく影響さるつものな り。從つて之れが䍃には嘘內の Flame zone K良 く注意する必要すれども、之れは瓦斯と空氣との 吹归口の傾斜度によりて左右さる」事大なるが故
に常にての傾科に就て多くの注意を拂ひ居れり。

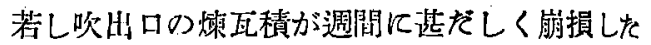
る場合には、此處に補助の煉瓦能をなして之を補 U、良好大る絬棵在得つ;西り。次の各溫度表及 び各曲線圖は、上述の各垶器其他を用ひて测定世 る結果を示するのなり。

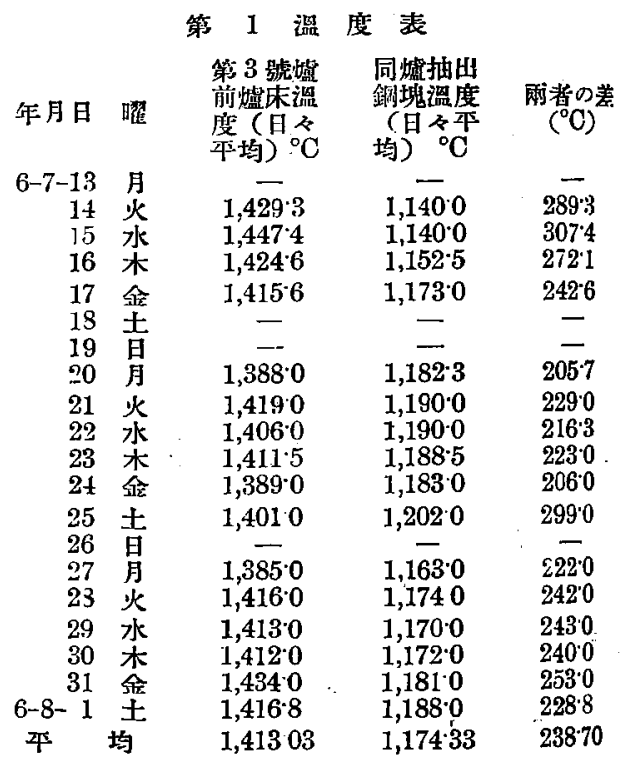

第 2 偲 度 表

\begin{tabular}{|c|c|c|c|c|c|}
\hline \multicolumn{2}{|c|}{ 月日 } & \multicolumn{4}{|c|}{ 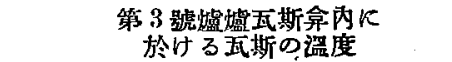 } \\
\hline 時 & & 7月14日 & 7月15日 & 7月16日 & 7月17日 \\
\hline$A M$ & $\begin{array}{l}7 \\
8\end{array}$ & $\begin{array}{l}430^{\circ} \mathrm{C} \\
430\end{array}$ & $\begin{array}{l}480^{\circ} \mathrm{C} \\
470\end{array}$ & $\begin{array}{l}530^{\circ} \mathrm{C} \\
510\end{array}$ & $\begin{array}{l}520^{\circ} \mathrm{C} \\
510\end{array}$ \\
\hline & 9 & 420 & 460 & $" z$ & $" 1$ \\
\hline & 10 & 430 & $"$ & " & 560 \\
\hline & 11 & $"$ & $"$ & 500 & 510 \\
\hline & 12 & " & 440 & 490 & 500 \\
\hline PM & 1 & $"$ & 450 & 500 & " \\
\hline & 2 & " & 440 & " & " \\
\hline & 3 & 440 & 430. & $"$ & " \\
\hline & 4 & 430 & 440 & 480 & 490 \\
\hline & 5 & 440 & $"$ & 490 & 500 \\
\hline & 6 & 430 & 450 & " & 490 \\
\hline & 7 & 440 & 440 & $"$ & " \\
\hline & 8 & 430 & 450 & 510 & 510 \\
\hline & 9 & " & 480 & 490 & 500. \\
\hline & 10 & " & " & & " \\
\hline & 11 & 410 & 500 & $"$ & $"$ \\
\hline & 12 & 460 & 490 & " & 490 \\
\hline $\mathrm{M}$ & 1 & $\begin{array}{l}430 \\
415\end{array}$ & $\underset{/ 7}{450}$ & 470 & $\underset{/ 1}{480}$ \\
\hline & 3 & $\begin{array}{l}+10 \\
390\end{array}$ & " & 470. & 460 \\
\hline & 4 & " & 460 & $"$ & 490 \\
\hline & J & - 410 & $" 1$ & " & 520 \\
\hline
\end{tabular}




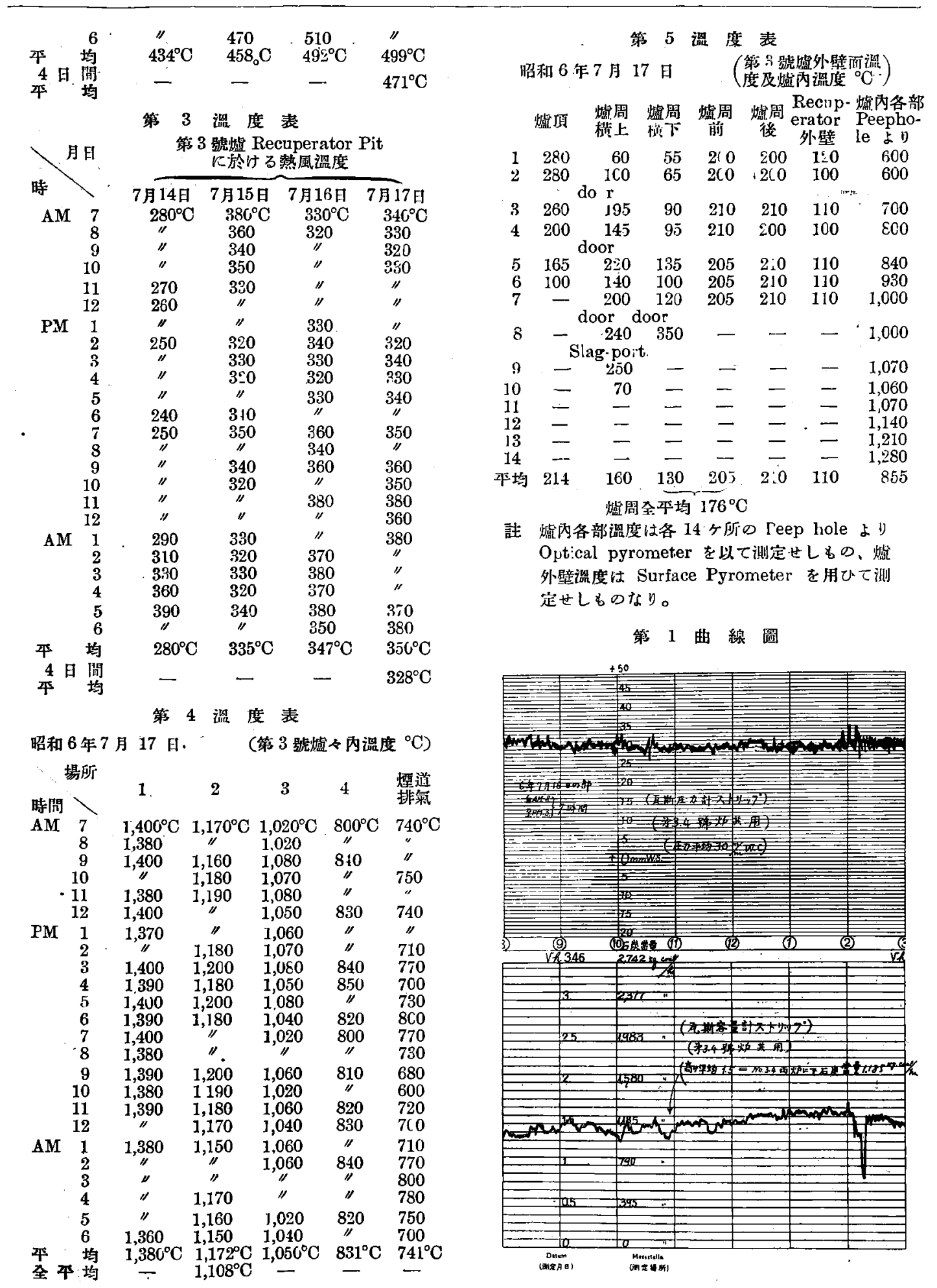


第 2 曲楾㘣 $\mathrm{CO}_{2}$ Recorder strip (7 月 16 日、第3 號嘘に於汀るもの)

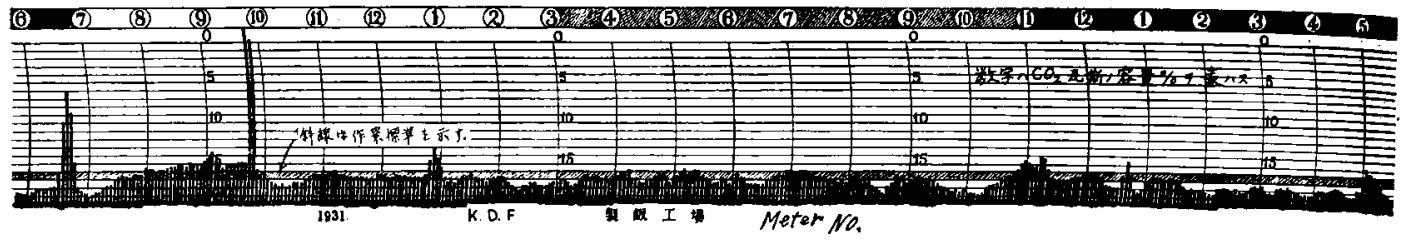

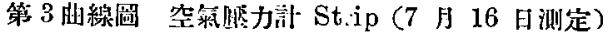

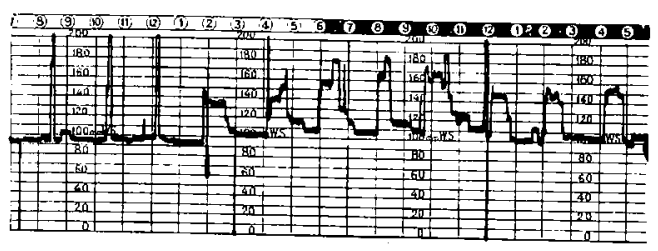

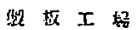

第 4 曲線圆 (第 2 渭度表對照)

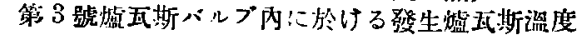

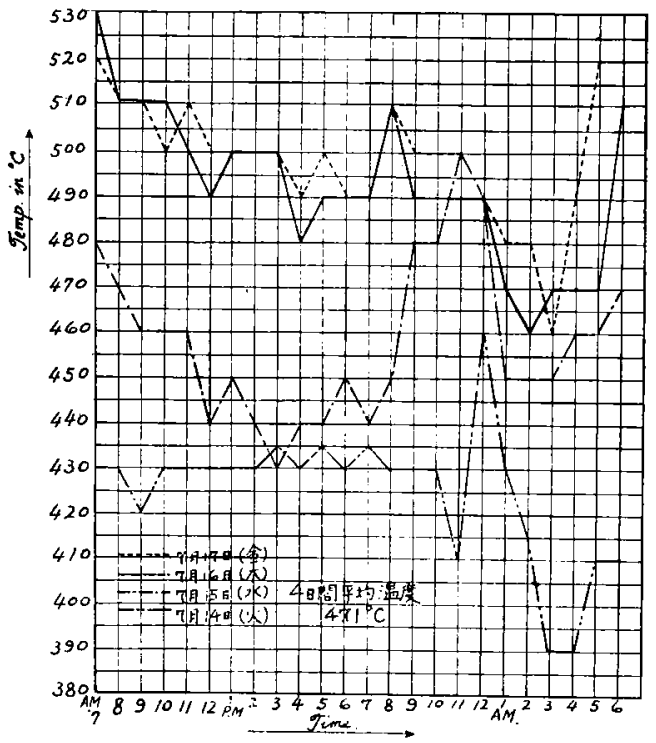

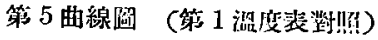

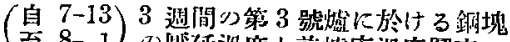

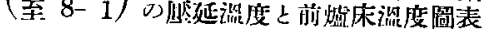

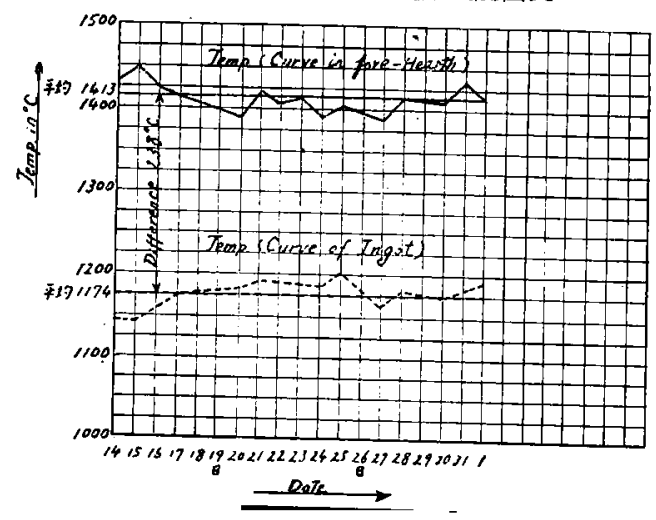

第 6 曲楾圆（第 3 沮度表對照）

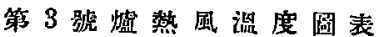

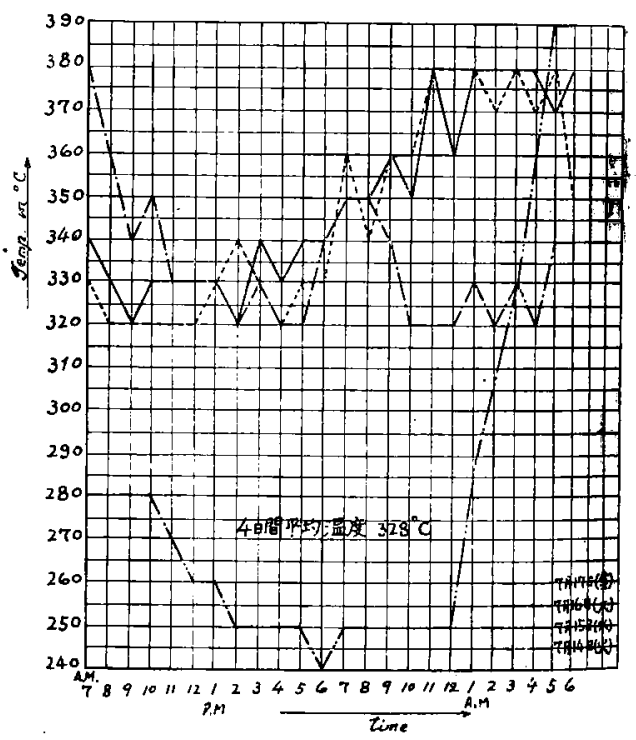

第 7 曲線圆（第 4 淰度表對照）

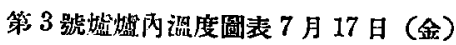

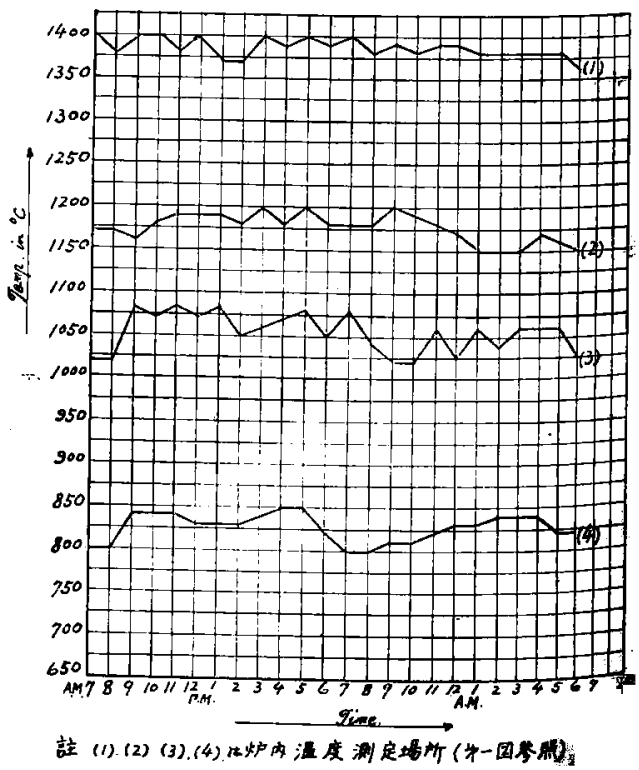




\section{3. 使用瓦斯量と空氣量との理論と實際} 當所第 2 酉斯工場より第 3 、第 4 號嘘に来る瓦斯 を、再斯拿つ所に於て 6 日間連續的に、8 時間每 に、Tank內に採集して分析したる結果を次に示 す。

\section{第 4 表}

$\left(0^{\circ} \mathrm{C} \& 760 \mathrm{~mm} \mathrm{Hg}\right.$. K於ける Volume \%) $\begin{array}{llllll}\mathrm{CO}_{2} & \mathrm{O}_{2} & \mathrm{CO} & \mathrm{CH}_{4} & \mathrm{H}_{2} & \mathrm{~N}_{2}\end{array}$ $\begin{array}{llllll}3.63 & 0.10 & 28.0 & 4 \cdot 80 & 10.42 & 53.05\end{array}$

上記組成瓦斯を燃燒せしむるに必要なる空氣量

を計算すれば次の如し。

\section{燃燒に必要なる $O_{2}$ の量は}

CO 者然やすに $0.28 \times 1 / 2=0.14 \quad \mathrm{~m}^{3}$

$H_{2} " 0.1042 \times 1 / 2=0.0521 \mathrm{~m}^{3}$

$\mathrm{CH}_{4}$ " $0.048 \times 2=\frac{(+) 0.096-\mathrm{m}^{3}}{0.2881} \mathrm{~m}^{3}$

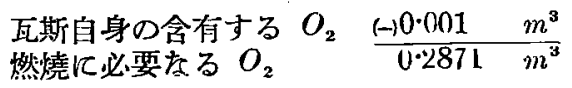

故に燃燒に必要なる空氣量は

$$
0.2871 \times \frac{100}{21}=1.37 \mathrm{~m}^{3}
$$

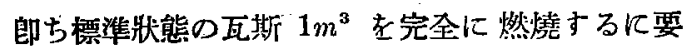
する空雨の量は $1.37 \mathrm{~m}^{3}$ なり。(但し瓦斯 $1 \mathrm{~m}^{3}$ 中 には實測上 Tar 44.1gr を含む事を知れ其。其の 幾分かは瓦斯道、瓦斯拿、內等俉るものなるが 故に、果してその何\%が爐內に入るかは不明なる 篇、計算上り除外せり。)

次沼和 6 年 7 月 13 日より同 17 日迄の. 第

3 號爐に於ける瓦斯と空氣との鿓際使用高老沙定 せる結果次の如くなれり。

\section{第 5 表}

$\left(0^{\circ} \mathrm{C} \& 760 \mathrm{~mm} \mathrm{Hg}\right.$. K於け 万 Volume in $\mathrm{m}^{3} / / \mathrm{hr}$ )

月日7月13日 14 日 15 日 16 日 17 日平均

瓦斯最 $1,542.51,292.51,695.01,860.01,990.01,692.0$

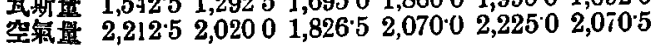

之より瓦斯量と空氣量との平均值の此老求むれば $1,692 / 2,070 \cdot 5=1 / 1 \cdot 23$
郎ち實際上に於ては瓦斯 $1 m^{8}$ 亿對して空氣 1.23 $m^{3}$ を使用せる事となる。之れは理論的完弪然燒 の割合より少けれ共、穓際は扉の開閉の爲及び屝 其他の部分の間吵慜上り爐內浐入する空氣老以 て補はるっものなるべし。

今ての實際使用瓦斯量の抈熱鋼塊玙當りを見ん に、抓熱銓塊は 1 日 720 偑なるが故に、單重 930 $\mathrm{kg}$ として、爁1基掌り 6.97ton/ hr となる。石炭 1 䣩の發生瓦斯量は鰂測の結果 $3,400 \mathrm{~m}^{3}$ なるが故 に、發生爈、瓦斯道其他に於ける損失を $5 \%$ とす れば、 $3,230 m^{3}$ となる。

故江平均使用瓦斯量 $1,692 \mathrm{~m}^{3}$ 石岸當量忙

$$
1,000 \times 1,692 / 3,230=524 \mathrm{~kg} / \mathrm{hr}
$$

にして、扣䓡銅塊䣩當り消費石炭量は

$$
524 \div 6 \cdot 97=75 \cdot 2 \mathrm{~kg} . \text { Coal } / \text { ton. Ingot }
$$

\section{4. 瓦斯の理論的燃燒溫慶已實際前爐床溫}

\section{度との比較に就て}

高熱瓦斯の發熱量 :一高熱瓦斯の發熱量は其の 瓦斯の比墨加ら計算せざるでからず。而して瓦斯 つ比熱は其の各組成瓦斯の各の比熱より計算し得

$$
\begin{aligned}
& \text { 即亏 } \quad S_{i}=\Sigma \frac{V}{100} \delta_{\mathrm{t}} \\
& \text { 式中 } \delta_{\mathrm{t}}=t^{\circ} \mathrm{C} \text { に於ける瓦斯の比熱 } \\
& \delta_{\mathrm{t}}=t^{\circ} \mathrm{C} \text { に於ける組成單瓦斯の比熱 } \\
& \mathrm{V}=\text { 組成單瓦斯の容㱴 } 100 \text { 分率 }
\end{aligned}
$$

單瓦斯の比蓺恃次の式上り算出す。 $\mathrm{CO} \mathrm{H}_{2}$ $O_{2} \quad N_{2}$ 空氣、及び氷丞氣は Mallard 及び Is Chatelier $^{1}$ ) E曰賽驗式により

$$
\begin{aligned}
& \delta_{\mathrm{t}}\left(\mathrm{CO} \mathrm{H} \mathrm{H}_{2} \mathrm{~N}_{2} \mathrm{O}_{2} \text { 空氣 }\right) \\
& \quad=0.303+0.000027 \mathrm{k} \mathrm{k.cal} / \mathrm{m}^{3} \\
& \delta_{\mathrm{t}}\left(\mathrm{H}_{2} \mathrm{O}\right)=0.34+0.00015 t \mathrm{k} . \mathrm{cull} / \mathrm{n}^{3}
\end{aligned}
$$

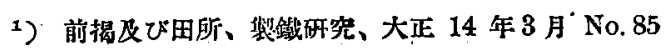


$\mathrm{CO}_{2}$ 及び $\mathrm{CH}_{4}$ は Richards²) 氏の䔈驗式に上

b

$\delta_{\mathrm{t}}\left(\mathrm{CO}_{2}\right)=0.37+0.00\left(22 \mathrm{k} \mathrm{k} . \mathrm{cal} / \mathrm{m}^{3}\right.$

$\delta:\left(C H_{4}\right)=0.38+0 \cdot 00022 t \quad k . c . s / m^{3}$

但 L.式中 $t=0^{\circ} \mathrm{C} \sim 2,000^{\circ} \mathrm{C}$

成分單瓦斯の量は第 4 表より

$\begin{array}{crr}\mathrm{CO} \mathrm{H}_{2} \mathrm{O}_{2} \mathrm{~N}_{2} & \mathrm{CO}_{2} & \mathrm{CH}_{4} \\ 91.57 \% & 3.63 \% & 4.80 \%\end{array}$

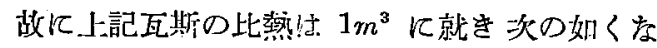
る。

$$
\begin{aligned}
S_{\mathrm{t}}= & 91.57 / 100(0.303+0.000027 t) \\
& +3.63 / 100(0.37+0.00022 t) \\
& +4.8 \cap / 100(0.38+0.00022 t) \\
& =0.309128+0.00004327 t
\end{aligned}
$$

高蓺瓦斯の發熱量は $\quad \mathrm{Q}_{\mathrm{t}}=\mathrm{Q}_{\mathrm{o}}+\mathrm{tS}_{\mathrm{t}}$

式中 $t$ は漓熱瓦斯の溫度 $=471^{\circ} \mathrm{C}$ (第 2 溫度 表より)

Qtは $0^{\circ} \mathrm{C} \& 760 \mathrm{~mm} \quad H g$. 亿於ける $1 \mathrm{~m}^{\mathrm{s}}$ の瓦斯が $t^{\circ} \mathrm{C}$ に熱せられたる場合の發 熱量

Q。は $0^{\circ} \mathrm{C} \& 760 \mathrm{~mm} \mathrm{Hg}$.に於ける $1 \mathrm{~m}^{\mathrm{3}}$

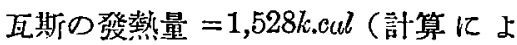
る)

故に $Q_{t}=1,683 k . c a l$ 灾り。

豫熱されたる空氣の有する熱量:一瓦斯 $1 m^{3}$ を 完全燃燒せしむるには空氣 $1 \cdot 37 \mathrm{~m}^{3}$ 要する 故 に、前記空氣の比熱式より

$\mathbf{Q}_{\mathrm{t}}{ }^{\prime}=\left(0.303+0.0000 \overline{2} 7 t^{\prime}\right) \times 1.37 t^{\prime}$

式中 $t^{\prime}$ は空藏が豫蓺せられたる溫度

1) 前拍及び田所、棐鋮研究、大正 14 年 3 月 No. 85 $=328^{\circ} \mathrm{C}$ (第3 溫度表より)

$\mathrm{Q}_{\mathrm{t}}^{\prime}$ は 0 C \& $760 m m$ Hy. 几於て $1 \cdot 37 m^{3}$ の宾氣が $t^{\prime}{ }^{\circ} \mathrm{C}$ に㣪熱せら れたる場合に有する熱量

故に $Q_{\mathrm{t}}{ }^{\prime}=169 k$.oul なり。

燃燒生成瓦斯を加熱するに必要江る熱量：一燃 生瓦斯忹 $0^{\circ} \mathrm{C} \& 760 \mathrm{~mm}$ Hg. 亿て二次の如成分 なり。

$\begin{array}{ccc}\mathrm{N}_{2} & \mathrm{CO}_{2} & \mathrm{H}_{2} \mathrm{O} \\ 1.4880 m^{3} & 0.2807 \mathrm{~m}^{3} & 0.2253 \mathrm{~m}^{3}\end{array}$

之を $t_{o}{ }^{\circ} \mathrm{C}$ に加熱するに必要なる熱量 $\mathrm{Q}_{\mathrm{t}_{\mathrm{o}}}$ は次 の式より求めらる。

$$
\begin{aligned}
Q_{t_{0}} & =\left(0.303+0.000627 t_{0}\right) \times 1.488 t_{0}+(0.37 . \\
& \left.+0.00022 t_{0}\right) \times 0.2807 t_{0}+\left(0.34+0.00015 t_{0}\right) \\
& \times 0.2253 t_{0}=0.631175 t_{0}+0.0001357 t_{0}{ }^{2} .
\end{aligned}
$$

使用瓦斯の理論的穄燒溫度上實際前爐床溫度と の比較:一瓦斯 $1 \mathrm{~m}^{3}$ 老 $t^{2} \mathbf{C}$ 亿豫熱し、之完全 に燃許せしむるに要する空氣 $1.37 m^{3}$ を $t^{\prime \circ} \mathrm{C} \kappa$ 樔熱して、此の瓦斯が此の空氣のみにて完全燃燒 をなし、發生したる髙量が。然生瓦斯の溫度を ${ }^{\circ} \mathrm{C}$ 几上昇せしむる霨にのみ費ざれたるものとす れば、次の式が成立す。

$$
Q_{t}+Q_{t}{ }^{\prime}=Q_{t_{o}}
$$

即与 $Q_{t}+Q_{t}^{\prime}=0.0001357 t_{0}{ }^{2}+0.631175 t_{0}$

そに $\mathrm{Q}_{t}=1,683, \mathrm{Q}_{\mathrm{t}}{ }^{\prime}=109$ を夫ネ代入すれば

$$
t_{\mathrm{o}}=2,000^{\circ} \mathrm{C}
$$

然るに實際Pyrometerによりて測定せし前嘘床 溫度は $1,413^{\circ} \mathrm{C}$ (第 1 溫度表より) なるが故に。 之れが理諭的燃燒溫度に對する比は

$$
1,413 / 2,000=0.7
$$

即ち $70 \%$ な。 


\section{5. 爐の熱平衡に就て 第3 號蠦に於ける昭} 和6 年7月 17 日測定せる結果を以て計算を行ふ ものとす。當日の畅 3 號嘘に於ける瓦斯使肘量平 均壮、第 5 表上り $1,990 \mathrm{~m}^{3} / \mathrm{hr}$. 原るが、今石炭 1 䣩の瓦斯溌生量は望測に依るに $3,400 m^{3}$ なるを以 て、 $1,990 m^{3} / h r$. の瓦斯の石若當量は

$$
1,000 \times \frac{1,690}{3,400}=585 \cdot 3 \mathrm{~kg} / \mathrm{hr}
$$

1 時間平均 1 基當 りの加熱銅塊䣩数は 6.97 的本 なるを以て

$$
585 \cdot 3 \div 6 \cdot 97=83 \cdot 6 \mathrm{~kg} . \text { Coal } / \text { ton. Ingot }
$$

となり、鋼塊 1 䣩を厚延温度に州热する等に 83.6 kg の石炭が消費さる。

銅塊が持去る熱量：一二今裴入さる」鋼塊の溫 度を $28^{\circ} \mathrm{C}$ とすれば、Carbon 含有量 $1.09 \% 、 M n$ の含有量 $0.36 \%$ の時、溫度 $1,200^{\circ} \mathrm{C}$ (實测化上 る溫度は $1,173^{\circ} \mathrm{C}$ をれども之を大體 $1,200{ }^{\circ} \mathrm{C}$ とせ り）なる鋼片 $1 g r$. の含有熱量は約 $\left.205^{1}\right) e c l$ な. bo

鋼塊 1 琌當りの石炭消費量は0-0836 䣩なるが 故に鋼塊 $1 \mathrm{gr}$. $1,200^{\circ} \mathrm{C}$ に州熱するに要する石 炭の熱量は

$$
6,870 \times 0 \cdot 08 \Sigma 6=574 \cdot 3 \mathrm{cal} .
$$

なり。故に鍴地 $19 r$ : が持去る等量は消費燃料に 對して

$$
\llcorner 05 \div 574 \cdot 3=35 \cdot 7 \%
$$

となる。郎ち消費燃料の $35 \cdot 7 \%$ を鍓地が持去る こといなる。この $35.7 \%$ は扠蓺爐が連續使媩せ られたる時ひ熱能率に相虽するものなり。

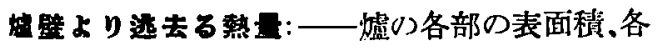

1) 海野、金㩯の研究 3 (1926) 225
部の溫度、煉瓦の熟傳導率箩索示せば次の如 L。

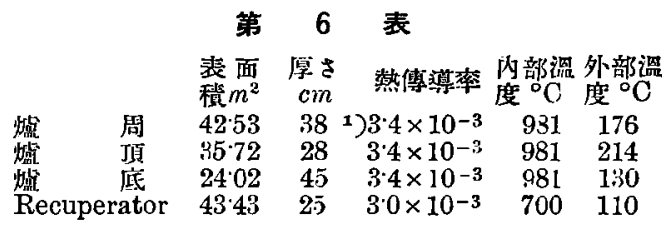

爐壁、Recuperator の壁等に用ひられたる煉瓦 は總て耐火粘土煉瓦なり。爐の橫壁の一方郎古中 間壁上りは慈の出入なしと考へ、嘘底は外氣に直 接面せる部分のみに就て考へたり。盔內溫度は Pyrometer に上る測定平均溫度 $1,108^{\circ} \mathrm{C}$ と各覘を ロより Optical Pyrometer にて测定せる平均溫度 $855^{\circ} \mathrm{C}$ との平均をとり $981^{\circ} \mathrm{C}$ とせり。

今爐周上门單估時間に流出する熱量在 R とす れば

$$
\begin{aligned}
& \mathbf{R}=\frac{3 \cdot 4 \times 10^{-3}(981-176) \times 42.53 \times 10^{4}}{38} \\
& =3(1,611 \text { eal }
\end{aligned}
$$

同樣汇計算すれば 爐頂は $\quad 24,513 \mathrm{cal}$ 嘘底は . $15,250 \mathrm{cal}$ Recuperator は $30,749 \mathrm{cul}$

$$
\text { 合計 } 101,123 \mathrm{cal}
$$

又單位時䦌に㷋生する慈量は

$$
\frac{6,870 \times 585 \cdot 3 \times 10^{3}}{3,600}=1,116,180 \mathrm{cal}
$$

なるを以て、全消費燃料に對する流出熱量の\%は

$$
101,123 \div 1,116,180=905 \% \text { な。 }
$$

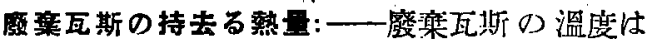
$741^{\circ} \mathrm{C}$ (第4 溫度表より)なり。外氣溫度 $28^{\circ} \mathrm{C}$ 迄 の降下に對して幾何の熱量を含むかを計算するに 空氣よ瓦斯との燃燒によりて生する塺寨瓦斯の量 は計算の結果 $3,600 \mathrm{~m}^{3} / \mathrm{hr}$.となる。

1) 宮良、帝國瓦斯垛合第 18 回諯演會研究發表、田 所、裴鐡所研究所研究悻告 6 (1926) No.6 


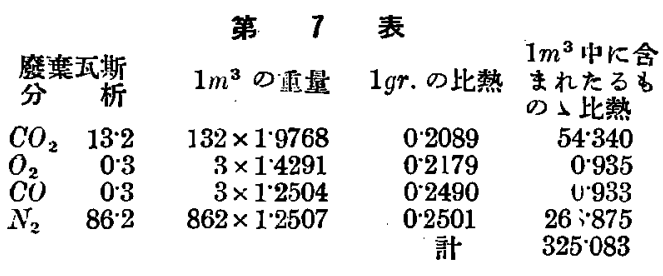

隨つて單位時間に於て排出する履亲瓦斯ボ氣溫

$28^{\circ} \mathrm{C}$ 迄の降下に對して流出する熱量 $\mathrm{S}$ は

$$
\mathrm{S}=\frac{3,600 \times 325.083 \times(741-28)}{3,600}=230,976 \mathrm{ccll}
$$

なり。故に全消費燃料に對しては

$$
230,976 \div 1,116,180=20 \cdot 6 \% \text { となる。 }
$$

锯涬の去る熱量:一一筫測によれば生成する 鑛滓の量は、加熱鋼塊の $1.5 \%$ なり。故に. 1 時間 には

$$
6,970,000 \times 0.015 \cong 105,000 \mathrm{gr} .
$$

となる。1 gr. 鑛㵏の溫度 $1,200^{\circ} \mathrm{C}$ に於て含有す る熱量は約 $300 \mathrm{cal}^{1}$ )なり。故に之れが單位時間 飞持去る熱量は

$$
\begin{aligned}
& \frac{105,000 \times 300}{3,600}=8,750 \mathrm{cal} \\
& \text { 全消費燃料に對しては： } \\
& 8,750 \div 1,116,180=0.78 \% \text { よなる。 }
\end{aligned}
$$

冷却水の持去る熱量:一一冷却水の量及び盜度 を羊せば次の如し。

\section{第 6 溫 度 表}

$$
\text { 入水温度 排水㴓度上开偲度 水 量 }
$$

Slide tube $23^{\circ} \mathrm{C} \cdot 72^{\circ} \mathrm{C} \quad 49^{\circ} \mathrm{C} \quad 1,500 \mathrm{gr} / \mathrm{sec}$ Chute block $23^{\circ} \mathrm{C} \quad 58^{\circ} \mathrm{C} \quad 35^{\circ} \mathrm{C} \quad{ }^{\circ} \quad 700 \mathrm{gr} / \mathrm{sec}$ Door frame $23^{\circ} \mathrm{C} \quad 60^{\circ} \mathrm{C} \quad 37^{\circ} \mathrm{C} \quad 616 \mathrm{gr} / \mathrm{sec}$

故に持去らるら熱量は

$$
\begin{array}{ll}
\text { Slide tube } & 1,500 \times 49=73,500 \mathrm{cal} \\
\text { Chute block } & 700 \times 35=24,500 \mathrm{cal} \\
\text { Door frame } & 616 \times 37=22,792 \mathrm{cal} \\
& \text { 合計 } 120,792 \mathrm{cal}
\end{array}
$$

なり。故に全消費然料に對しては

$$
120,792 \div 1,116,180=10 \cdot 82 \% \text { よなる。 }
$$

1）海里、金閔の研究 6 (1928) 236
Recuperator の回收熱: 一一外氣溫. $28^{\circ} \mathrm{C}$ K於 ける空氣が Recuperator orifice 老通つて间收す る熱量を求むれば、作業中沉於ける平均の熱風溫 度は $350^{\circ} \mathrm{C}$ 、到風量は $2,225 \mathrm{~m}^{3} / \mathrm{hr}$.（第 3 溫度表 及び第 5 表より）なるが故に、單位時間に回收す る熱量柱前記の Mallard 及び Ie Chatelier ${ }^{1}$ )氏 の實驗比較式により計算すれば

$$
\mathrm{Q}^{\prime}=62,142 \mathrm{cal}
$$

なり。故に全燃料に對しては

$$
62,142 \div 1,116,180=5 \cdot 57 \% \text { となる。 }
$$

\section{第 3 號烓に於ける熱量配布:一之等の計算の} 結果を綜合すれば第 8 表の如し。鋼塊其他へ消費 せらる〉熱量と四收熱量との差を $100 \%$ よ減ぜ し $28.62 \%$ は、發生爐に於ける瓦斯化の䈆、瓦斯 道壁、Recuperator 基礎等より大地一流出せる

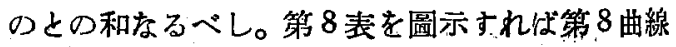
圖の如くなる。

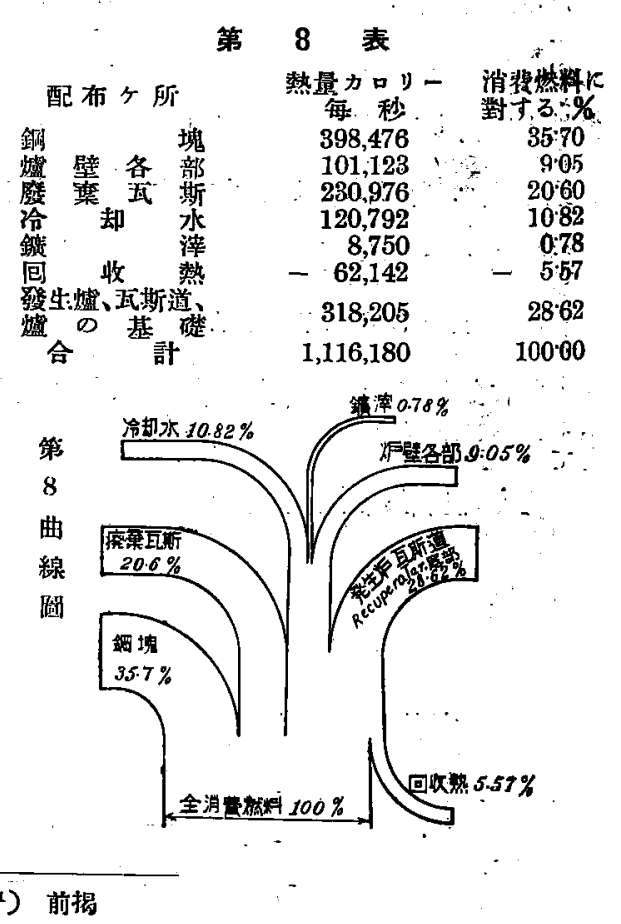




\section{III. 涯延機に就て}

\section{1. 㢈延機及び其の附屬設備 (第 1 圖及び蒚畺殄}

照）压延設借の特微は、鋼塊より製品に至る艺。 終始一貫殆んど人手を要せす、、奎部機械的に作業 し得る如く設計しある事なり。

涯延機を大別して荒ロール機 (Vorwalzenstrasse) と、連續口ール機 (Kontin Stragse) とす。荒 ロール機㤌何れも760 roll (Triowalzen) ๑第 1 、第 2 荒口 ール機より成り、第 1 荒ロール機は前 後面に、第 2 荒口ール機は後面のみに Tilting table t有し、且つ兩荒ロール 機共前面に第 $4 ， 5$ 圖に示すが如を自
動轉这裴置 (Kantvorrichtung) を俏す。又第 1 荒 ロール機前方の Roller table の中閒には、第 6

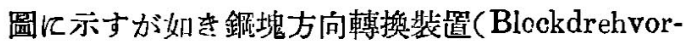

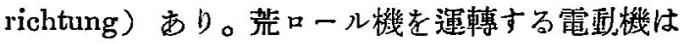
三相交流誘導電動機にして $1,440 \mathrm{kw}, 2,200$ ボル ト、625アムペア、8 回轉每分、60サイクルのb のなり。

第 4 圖 平銅工場第 1 荒口ー几機銅片轉运蓄置
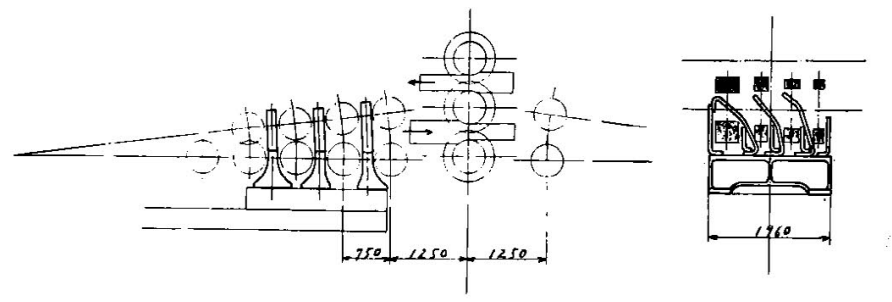

荒 口 $-n$ 機

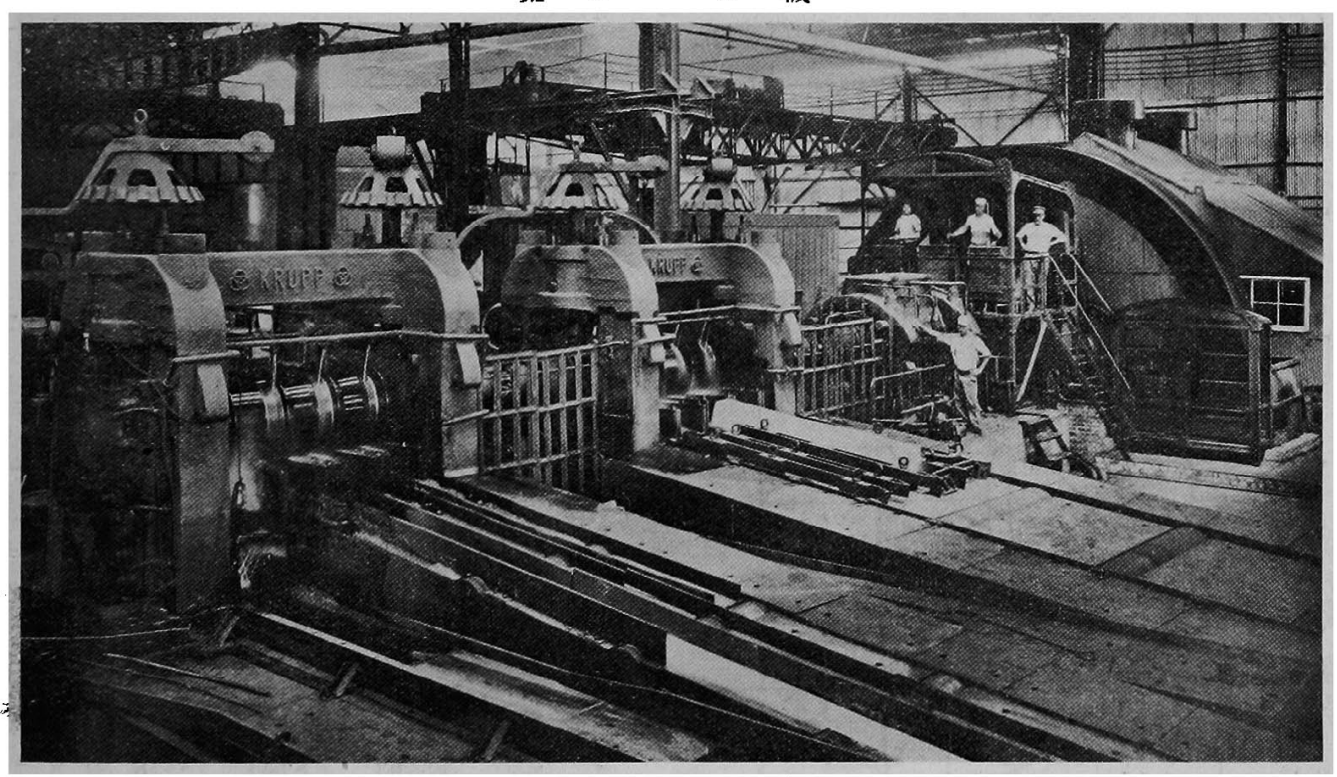

第 5 圆 平銅工場第二荒ロール機銅片签征裝置

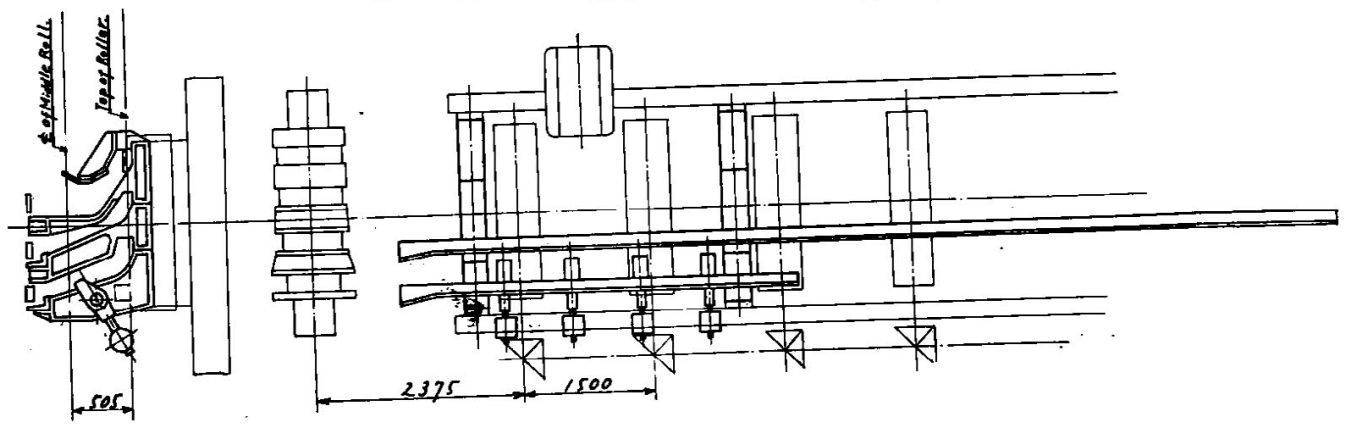


蓮総ロール機及びクーリングテープル

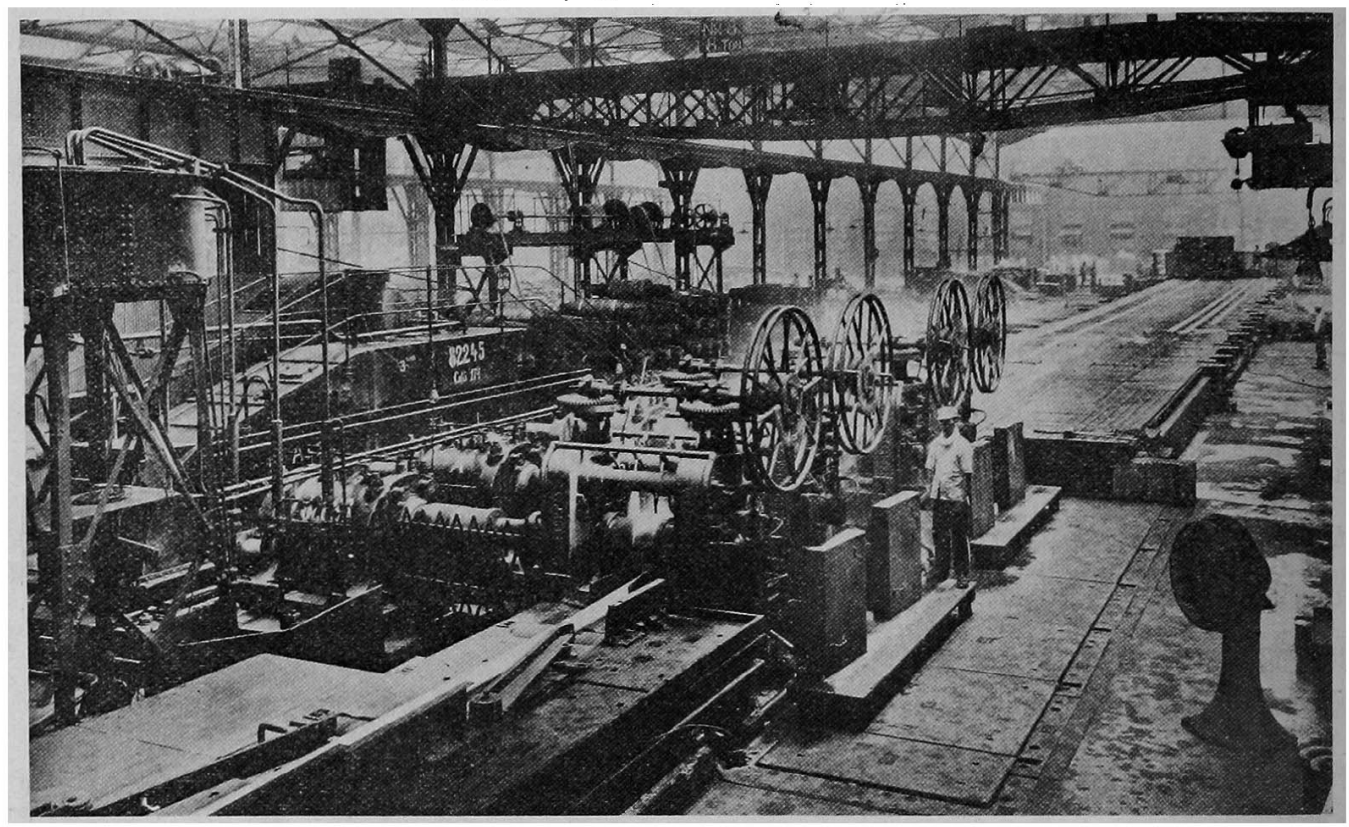

第 6 圆 平銅工場銅塊方向轉换装置

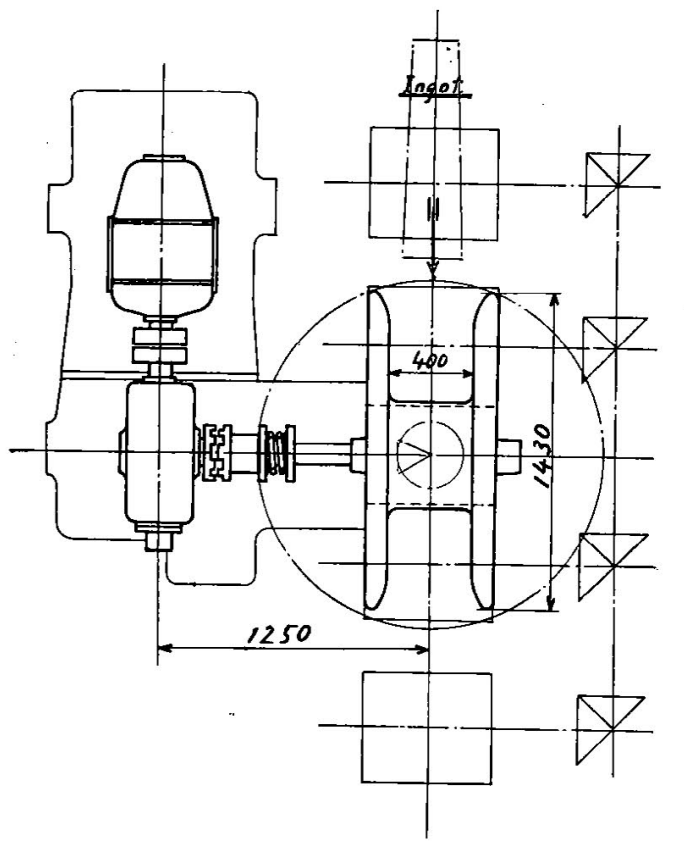

連續口ール機は 4 組の $460 \phi$ 'Two high roll (Duowalzen)より成り、その各ネの包轉數は每分 62,86,120,167，なり。之を運轉する電動機は同
梯三相交流誘導電辞機にして、1,75! kw, 2,200 ボ ルト、594アムペア、255 包轉每分、60サイクル のものなり。

2. シートバー壓延作業方法

（1）製品の種類 當工場で最も多く製作する シートバーの種類支第 9 表に示す。

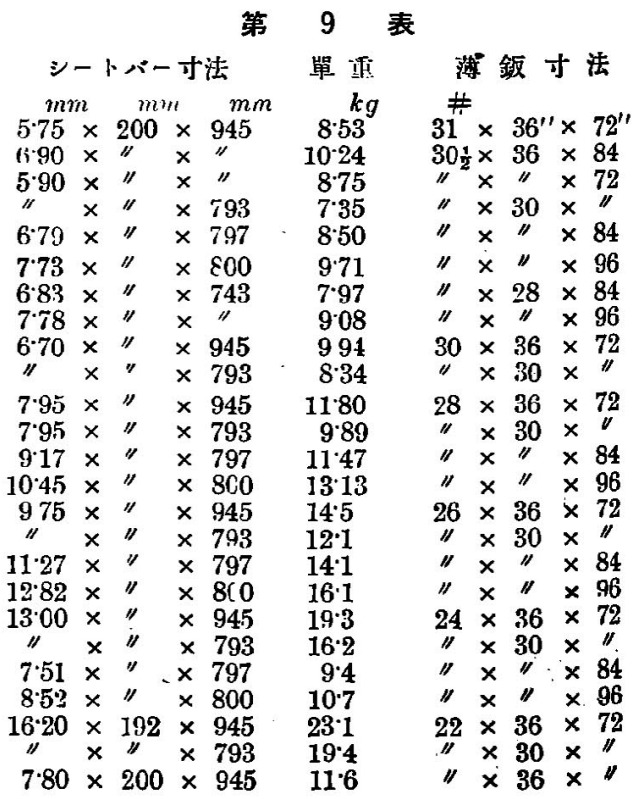




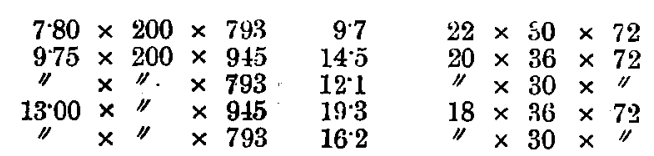

（2）使用口ール 當工場にて使用するロール は次の第 $7 、 8$ 圖に示す如きものなり。
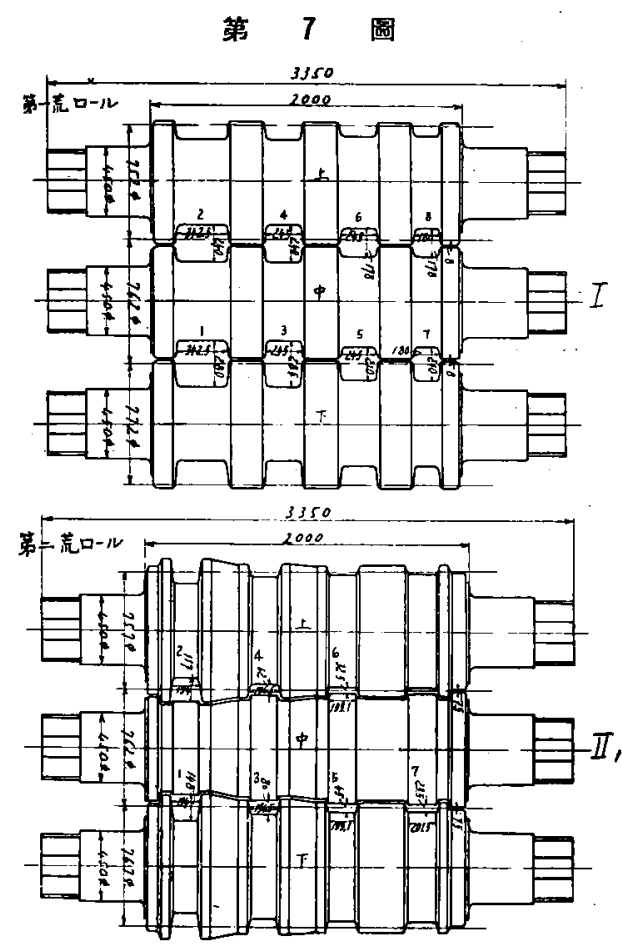

製造所别の大體の分析を示せば次の如し

第 10 表 第 1 流ロール (Forged Sleel, Schmiedestahl)

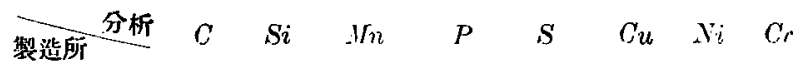

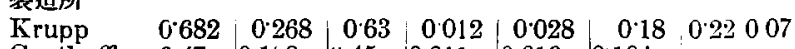
Gusthoff- $\quad 0.47 \sim 0^{\circ} 113 \sim 0^{\circ} 45 \sim 0.011 \sim 0.016 \sim 0.104 \sim$

$\begin{array}{llllllll}\text { nungshütte } & 0.66 & 0.25 & 0.84 & 0.041 & 0.038 & 6.31\end{array}$ 川崎車桷 $0.31 \sim 0.12 \sim 0.56 \sim 0.018 \sim 0.013 \sim 0.2 \sim$

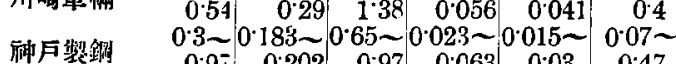
\begin{tabular}{llllll|l|l|l}
\hline & 0.97 & 0.202 & 0.97 & 0.063 & 0.03 & 0.47 \\
\hline
\end{tabular}

速㐨第 $1,2,3$ 口ールは第 1 荒ロールと同㥞なり。

第 11 表 第 2 茫口ール(Special cast iron, Spezialgusseisen) 製造所 分析 $C$

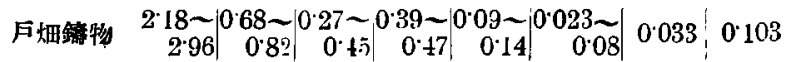

第 12 表 速維第 4 口ール(Chilled cast iron, Hartgusseisen)

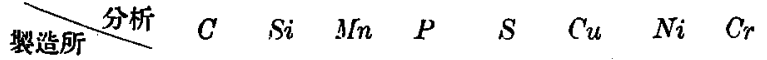

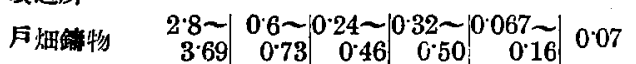

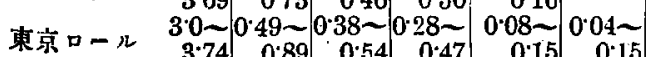

管 8 圖

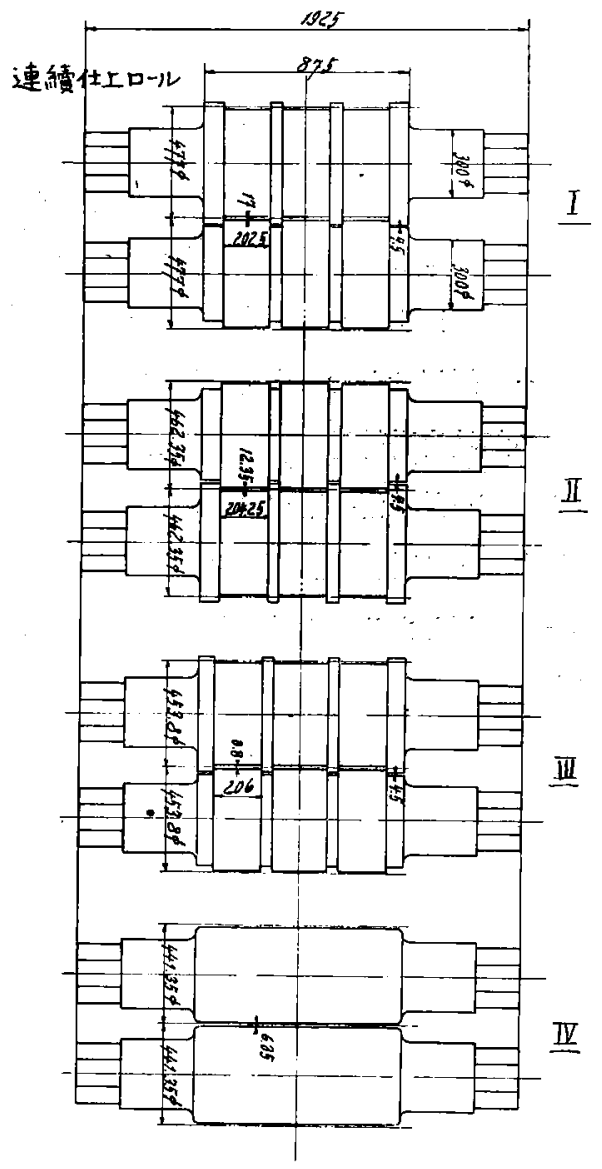

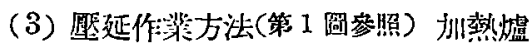
に於て約 $1,200^{\circ} \mathrm{C}$ に州熱せられたる鋼塊 は、爐より抽出され。（3）の搬出裝置に より（4)の Roller table に载せられ。 (9) の第 1 茓ロールに運代る。若し銅塊 が尻(大口)を先にして來りたる時は、(5) の鋼地方向轉換裝瞖により水平に $180^{\circ}$ 回鳔せしめ頭(小口)を先にせしさ。第 1 荒ロール符1カリバー（Kaliber）を通 過すれば、(6)の Tilting table を与げ て第2 2 カリバーを通過せしむ。炏にての 
Tilting table を下ぐれば、第 4 圖に示せる鋼塊 自動轉邆裴置つ墈により，自動的に横に 9 八 $^{\circ}$ 回轉 して第 3 カリバーに迩らる。之を繰返して第 8 カ リバーを战でたる鋼塊は、(10)のConveyor (Schlepper）に上り第 2 荒口ール前面の Roller table に運な゙る。次に第 2 荒ロール第 1 カリバーを通過 すれば、同栐 (14)の Tilting table により第 2 カリバーを通過せしむ，之を通過すれば、第 5 圖 に示せる鋼塊自動轉揆裝圆の働により、自動的に 符 3 カリバー前に滑り落つ。(ての際裴面のスケー ル (Schlacke) は幾分㧤落す)之を繰返した第 6 カ リバー在通過したるものは、(12)の盖斷機により 2 等分及び頭と尻との不良部分を切り捨てられ。 第てカリバーに迼らる。(第7 7 カバーの出口に於 て櫴出を以て表面のスケールを完全に落さしむ） 之を出机代 (15) の Roller tableにより (16) の連縕ロールに送られ、規定の厚さ及び幅に壓延 され。(19)の Cooling table K至る。此處にて 冷却の後、(20)の剪斷機により規定の長さに切斷 され、(21)の搬忛裝置により整理場 (Zurichterei) に運ばる。

(4) 連繮ロール調節法 第 9 表に示せる如く當 工場にては可成り多種類のシートバーを製作す。 從つて連繯ロールの調節變更が座々必要となる。 この場合先づ大體の見當で調節を行ひ次いで精細 なる調節を段をに行ひ行けば。遂には規定の厚さ 及び幅のものを得るに至れども、この方法にては 規定のものが出來る迄には、相當の出來損いが出 來且つ相當の時間をも空費し、甚だ不經洲の上に 作业能率をる甚だしく害するが故に，當工場にて は次の如き方法を用ひ、一瞬時間に 1 本の出來損 いも造る事なく、作業をなしつょすり。
郎ち連續ロールル於ける所謂琏れもせする張られ もせず (Keine Sohlinge und nicht zichen) と云 ふ條作より出發し次の式を得。

$$
\mathrm{F}_{1} \mathrm{~V}_{1}=\mathrm{F}_{2} \mathrm{~V}_{2}=\cdots=\mathrm{F}_{\mathrm{n}} \mathrm{V}_{\mathrm{n}} \cdots \cdots(\mathrm{I})
$$

式中 $F=$ Crnss sectional area of sheet bar in

"Kaliber" $=\mathbf{b} \times \mathrm{h}$

各カリバーに於けるシート バーの饾は Geueze ${ }^{1}$ )氏の 筫驗式 $b=0.35\left(h_{1}-h_{2}\right) r$

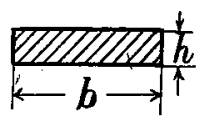

より、第2 荒ロールを出でたる寸法 23.5 (厚 さ) $\times 198$ (幅)より求むれ代

$$
\begin{aligned}
& b_{1}=200, \quad b_{2}=202, \quad b_{3}=203, \quad b_{4}=204 \\
& V=\text { Rolling speed }=\frac{\pi D n}{60} \\
& D=\text { Dia of roll } \\
& \quad D_{1}=460, D_{2}=450, D_{3}=445, D_{4}=435 \\
& n=\text { r. p. m. } \\
& n_{1}=62, \quad n_{2}=86, \quad n_{3}=120, n_{4}=167
\end{aligned}
$$

之等を全部 $(I)$ に代入すれば次の如くなる。

$$
0.298 \mathrm{~h}_{1}=0.409 \mathrm{~h}_{2}=0.567 \mathrm{~h}_{3}=0.775 \mathrm{~h}_{4} \cdot \text { (II) }
$$

上式より各た $\mathrm{h}$ の係数の比を求されば

$$
\begin{array}{r}
0.775: 0.567=1.37: 1 \\
\prime \quad: 0.409=1.89: 1 \\
\prime \quad: 0.598=2.6: 1
\end{array}
$$

郎ち此等の比を利用するるのにして。一侧を以て 示せば次す如し。

今現在厴延中のシートバーの厚さ、郎ち $h_{+}$よ

り $2 m m$ だけ厚を(或は薄き)シートーバーを得ん とすれば

第 3 機師ち $\mathrm{h}_{3}$ を $\quad 2 \times 1.37=2.74 \mathrm{~mm}$

第 2 機郎ち $h_{2}$ を $\quad 2 \times 1.83=3.78 m m$

1) Tafel, Walzen und Walzenkalifrieren S. 42 
第 1 機郎ち $\mathrm{h}_{1}$ を $\quad 2 \times 2 \cdot 6=5 \cdot 2 \mathrm{~mm}$

夫そ各機の娾下裝置(Anstellvorrichtung) 亿より。

望下を上ぐ(或は下ぐ)ればよきわけなり。

當工場にてはからる簡便なる方法を用ひ、實作 業.上非常なる便宜を得つ」あり。

3. 厘延作業惯績 創業當初は作業不慣れの䈆 口ール折損其他の故障多く，從つて壓趜括數も少 く，且つ牛成率高く、從つて製品步止りも甚だ不 良なりされども、次の第 13 裴に示すが如く、然 時日の間に急速の進步を逐げ得をり。斯くして今 日にては次の第 14 表に示すが如く、㱠んど理想 几近を好成績を舉げつなあり。第 15 表は:創翡よ り今日に至る迄のロール折損數を示すものなり。 而して第 9 曲線圖恃第 14 表を圖示したるのをり

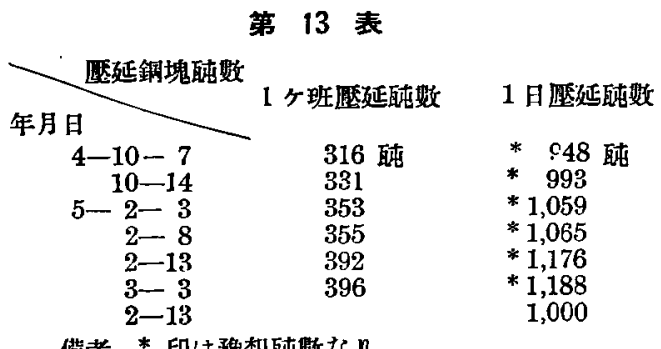

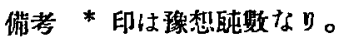

第 14 表 皇延成綪表

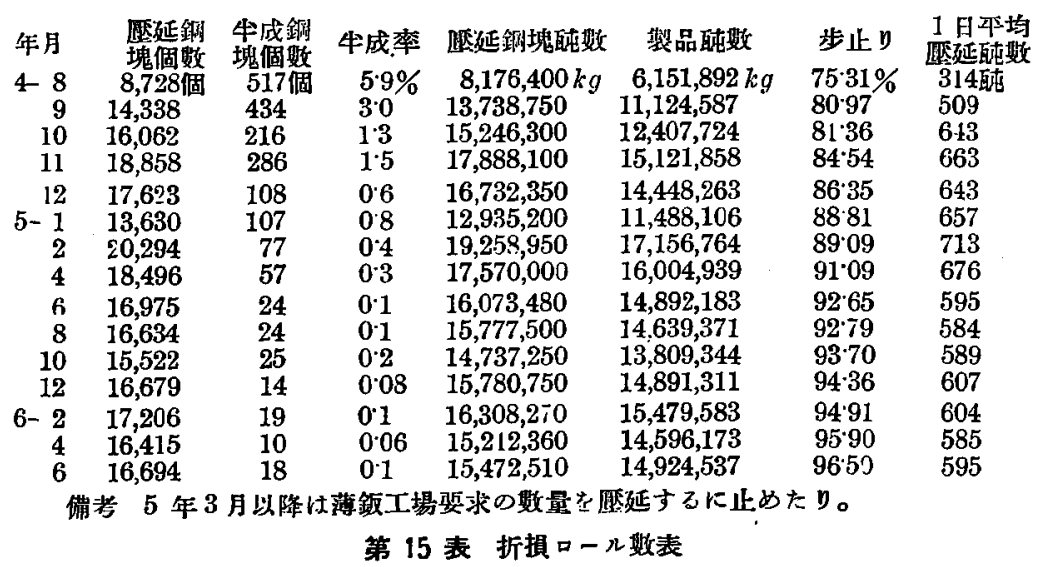

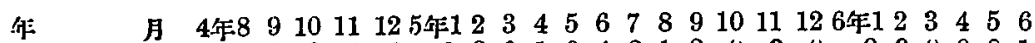
第 1 荒口－几

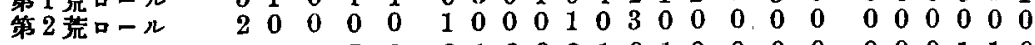

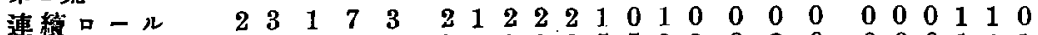
荅

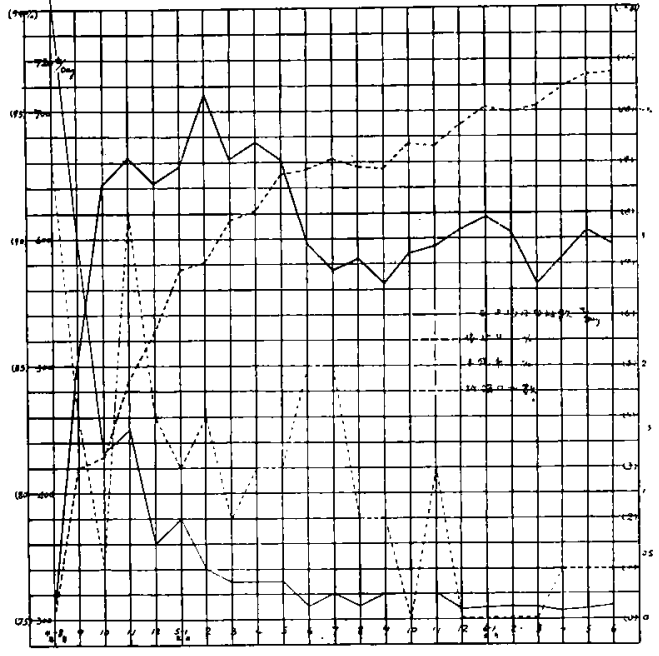

\section{4. 壓延譏の給具方法の改善による電力の節減}

當工場は初め獨逸人技師及び職長の指導のもとに 作濰を開始したるものにして、壓延機のロールネ ツクベャリングの給油方法もその指導により、冷 却水を主とし、グリース(揢融點 $110^{\circ} \mathrm{C}$, 灰分 $\left.13 \%\right)$ を從とせり。從つてグリースによる折角の潤滑膜 も、ての多量の水の焉押破られ、グリースはその 役目をる潤滑作用をなし得す。之の篇に州熱盧に

於ける銅塊州㬎作策の上 達にも係らず、低然とし て電力の低下を見ず，且 つロールネツク及びべヤ リングメタルの䐳隇可 成り甚だしきものであつ た。其處で給泊方法を改

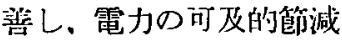
をなすへくくグリースの 归衰活用の一方便とし て。これが潤滑作朋を防 ぐる冷却水を廢して汇如 


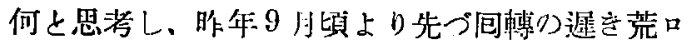

一ル機の一部分、連繥口ール機り的 1.2 機のべ

ヤリングに之を望施したるに、策外の好成績䒚得

をるを以て之に勢を得、本年 2 月頃上り回轉の速

き連續口ール機の第 $3 、 4$ 機及び其他全部のべヤ

リングに反復湅習の結果實施し得、次の第 16 表 及び之より得をる第 10 曲線圖に示すが如き多大

\section{比较つ一例なり。}

即ち水を使用せる場合 $210 \mathrm{kw} / \mathrm{sec}$ 。 水を使用せざる場合 $160 \mathrm{kw} / \mathrm{sec}$ 即ち單位時間に於て 電力約 $24 \%$ 節約と索る。 之は水を止めてしまつて作览する事が、如何に電 カの節減に對してて有效なるかを筫證するものな b。

\section{5. 壓延機の仕事に關する實驗} との筫驗は 1 個の鋼塊が各カリバー 〔第 1 荒ロール機 8. 第 2 荒 ロール機 7. 連續口ール機 4. (但し同時に通過)) を通過する每に、Motor より與へらる 1 訨事を笔力自動記錄計の記錄したる

第 11 曲線 阔 水を使用せし場合と使用せざりし場合との連綡 ロール機に於ける Idle running の策力比较

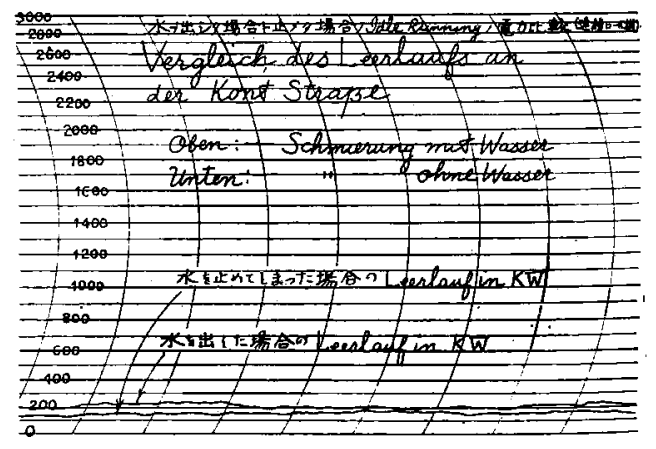

第 12 曲線圖の Power curveより、Fly wheel 加 ら與へらるっ仕事を、Fly wheel の Kinetic energy の減少より夫ょ實測及び計算によつて求め. 之を加へ合せて各カリバー每に與へらるっ仕事を 順次求め、最後に之等總てを加へ合せて 1 個の鋼 傀がシートバーに壓延せらる」迄に與へらる」全 仕事を求めをり。而して Motor より與へらる」 仕事は。之を機栈の總ての摩擦に打ち勝ちて壓延

1) Sebreyer, Archiv F. D. Eisenhiittenweren S. 117 
シートバー・ミルに就 て

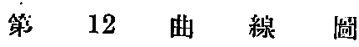

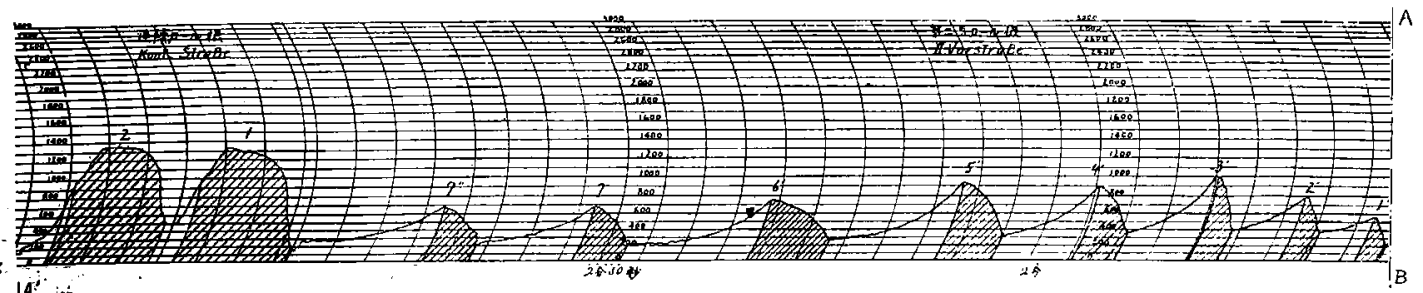

A it

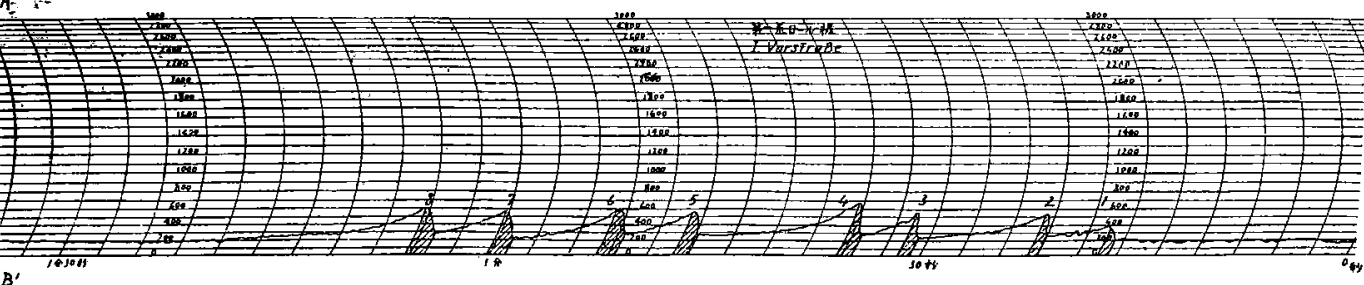

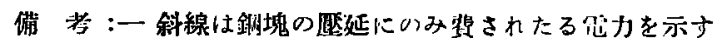

機を Running の狀態になすに必要なる仕事(Idlo

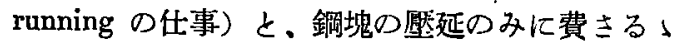
仕事とに分つ事の出秝るものなり。 次に Fly wheel より與へらるっ仕事は次の式に 上り求级らる。 $\mathrm{E}=\frac{\mathrm{J}}{2}\left[\left(\frac{\pi \mathrm{n}_{1}}{3 \prime}\right)^{2}-\left(\frac{\pi n_{2}}{30}\right)^{2}\right] 0 \cdot 000002728 \mathrm{kwh}$ 式中 $J=M$ Moment of inertia of fly wheel

$$
\begin{aligned}
& =57,600 \mathrm{mk} \cdot \mathrm{g} / \mathrm{sec}^{2} \text { (荒口一几機) } \\
& =4,700 \mathrm{mkg} / \mathrm{sec}^{2} \text { (連縵口一儿機) } \\
& \mathrm{n}_{1}=\text { 噶み始めの r.p.m. } \\
& \mathrm{n}_{2}=\text { 㟷み終りの r.p.m. }
\end{aligned}
$$

次の第 17 表岷ての資驗の結果を示すものなり

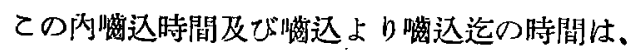

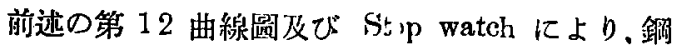
塊溫度は覧延機の後而しかも第1 カリバー通過後 のものなみを、Optical pyrometer により測定せ り。爐より出たる直暧の溫度は、Scale (Glïhspan) の鹪に確なる値を得られさるを虑り之を省をた り。 $\mathrm{n}_{1}, \mathrm{n}_{2}$ 挝轉計に上り精密に測定世るものな り之によりMotorより與へられたるIdle running 古含む金仕事は $10.97 \mathrm{kwh}$. Fly wheel より與
へられをる全江洜は $7 \cdot 011 \mathrm{kwh}$ 台計銅塊より製

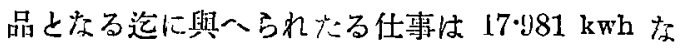
る事老知る。第 13 曲線圆はての賽驗より得たる

第 13 䌷線 䊅

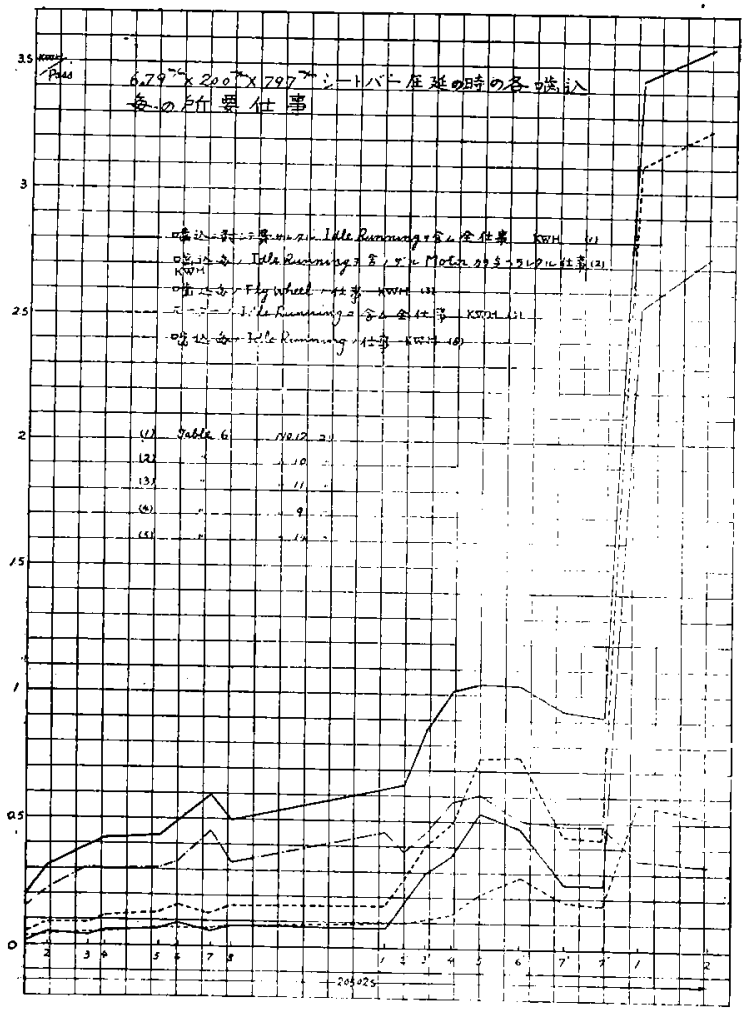


$\frac{1}{i=} \quad$ 窟

< $\quad$ काष 0 i⿱

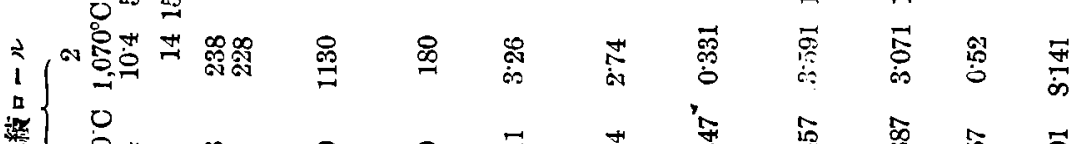

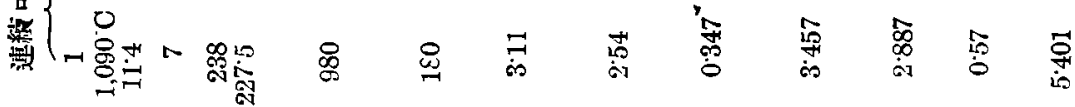

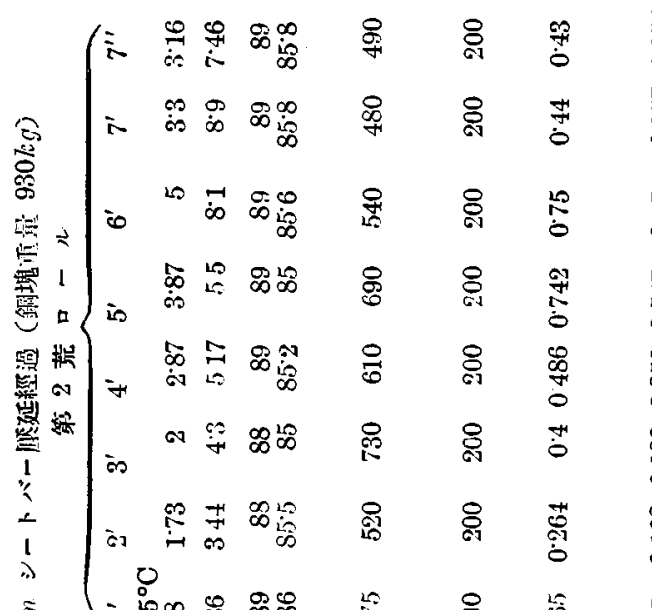

落 夏

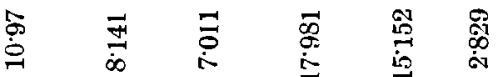

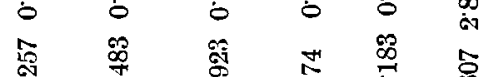

बे के में

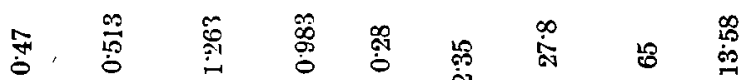

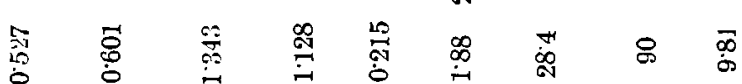

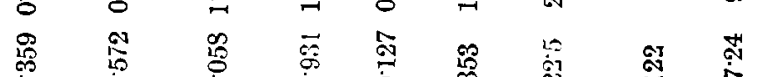

क ए

我

$\stackrel{0}{0}$

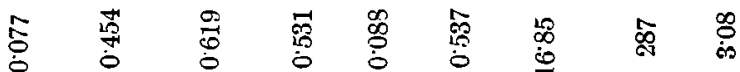

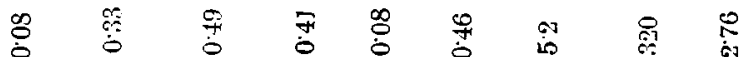

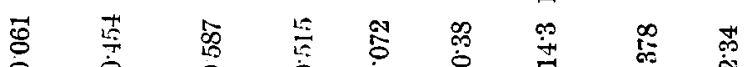

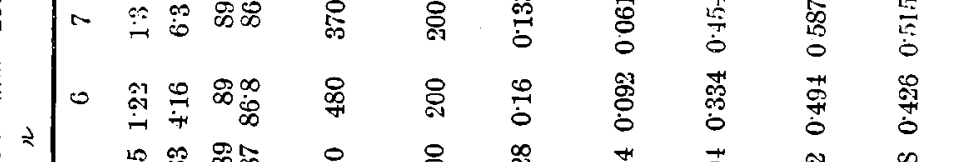

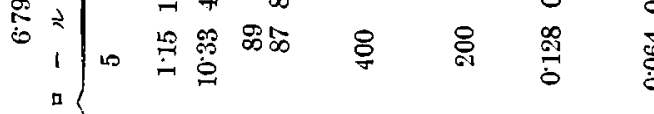

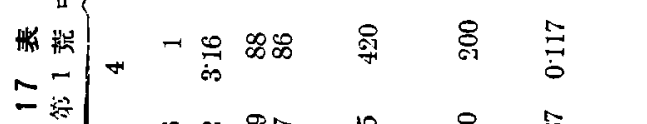

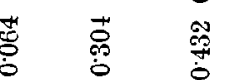

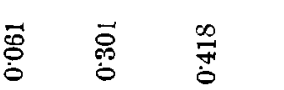

镭

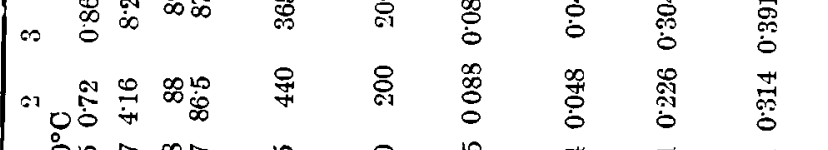

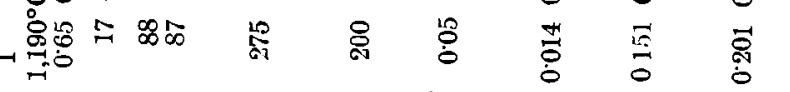

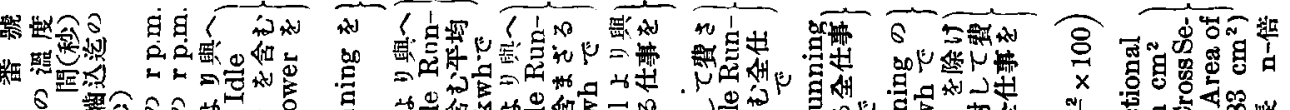

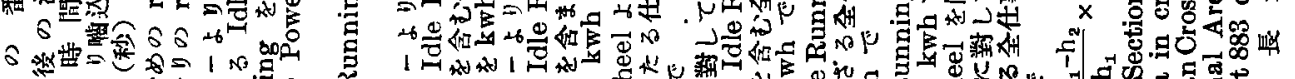

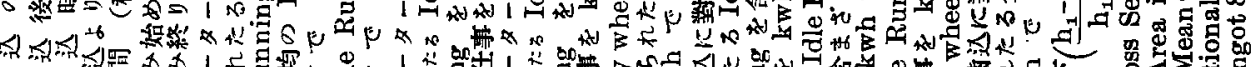

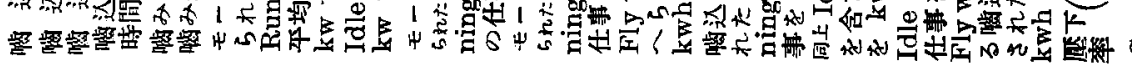

$\odot \quad \approx \quad \cong$ $\because \pm$ $\stackrel{20}{7}$
喽

惿点

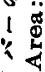

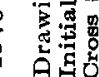

횸 


$$
\text { シートバー・ミルル就て }
$$

紹果を圖示せるものなり。之により各カリバー每 $の$ Motor 及び Fly Wheel の仕事老明膫に知 り得。 次の第 14 曲線圖は鋼塊を種々の溫度 $\left(1,190^{\circ} \mathrm{C}\right.$ 。 $3,150^{\circ} \mathrm{C}, 1,120^{\circ} \mathrm{C}$ ) 亿办茥し、鋼塊办熱溫度のMotor の雼す仕事に及症す影響を賽驗しをるるのなり。 郎ちその差の最も甚だしく現れたる第2 荒ロール 機第 6 カリバー $\left(6^{\prime}\right)$ に就て之を見るに、 $1,190^{\circ} \mathrm{C}$

第十四曲線圆

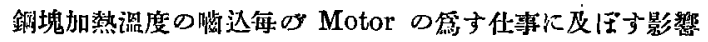

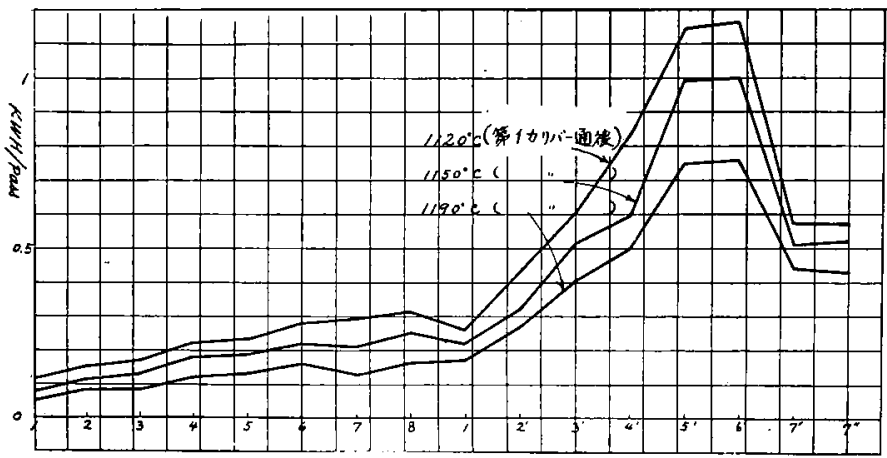

と $1,150^{\circ} \mathrm{C}$ とにては，溫度約 $3 \%$ 。隆下に對し て增加電力量は約 $33 \%, 1,190^{\circ} \mathrm{C}$ と $1,120^{\circ} \mathrm{C} に て$ は、溫度約 $6 \%$ の降下に對して增加電力量は約 55 \%なり、郎ちその影響の点たしきに警かさるっも のなり。

本稿を終るに當り御指導を賜りをる川崎造船所 㱔鈑工場小森富作、䗋谷知十雄及び新納鐵浐の三 E. 並に州熱爐心熱平衡につき 御敉示を賜りをる製鐵所理學博 士海野三朗氏並に㰮延機の仕事. に關する筫驗につき御教示を賜 りたる恩師京都帝國大學工學部

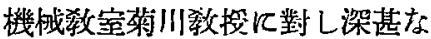
る感謝を捧ぐるものなり。 